Reviu Akuntansi dan Bisnis Indonesia, Vol. 5 No. 1, Hlm: 55-78, Juli 2021

Website: http://journal.umy.ac.id/index.php/rab

\title{
Determinan Fraud Dana Desa: Pengujian Elemen Fraud Hexagon, Machiavellian, dan Love of Money
}

Erni Suryandari; Lisdi Valentin*

Program Studi Akuntansi Universitas Muhammadiyah Yogyakarta

\begin{tabular}{l}
\hline I N F O A R T I K E L \\
\hline Kata Kunci: \\
Teori Fraud Hexago; \\
Teori Atribusi; Fraud \\
Dana Desa; Machiavellian; \\
Love of Money; \\
Religiusitas \\
Jenis Artikel: \\
Penelitian Empiris \\
Korespondensi: \\
valentinlisdi@gmail.com \\
Proses Artikel: \\
Diterima: 1 Mei 2021 \\
Review: 28 Mei 2021 \\
Review: 2 Juni 2021 \\
Revisi: 25 Juni 2021 \\
Diterbitkan: 1 Juli 2021 \\
Sitasi: \\
Suryandari, E., \& Valentin, \\
L. (2021). Determinan \\
Fraud Dana Desa: \\
Pengujian Elemen Fraud \\
Hexagon, Machiavellian, \\
dan Love of Money. Reviu \\
Akuntansi dan Bisnis \\
Indonesia, 5(1), 55-78.
\end{tabular}

Link Artikel:

10.18196/rabin.v5i1.11688

\author{
A B S T R A K \\ Latar Belakang: Maraknya kasus Fraud di Indonesia dari tahun ke tahun \\ yang merambah hingga ke Desa.
}

Tujuan: Untuk menganalisis pengaruh Tekanan, Kesempatan, Rasionalisasi, Kompetensi, Arogansi, Kolusi, Sifat Machiavellian, dan Sifat love of money terhadap Fraud Pengelolaan Dana Desa serta Religiusitas sebagai pemoderasi variabel Rasionalisasi, Sifat Machiavellian, dan Sifat love of money terhadap Fraud Pengelolaan Dana Desa.

Metode Penelitian: Sampel penelitian ini adalah aparatur pemerintah desa dalam lingkup pemerintahan desa di Daerah Istimewa Yogyakarta yang berjumlah 203 orang. Jenis data yang digunakan adalah data primer. Penelitian ini menghasilkan sebelas hipotesis yang diukur dengan alat analisis SEM-PLS menggunakan aplikasi SmartPLS v3.3.2.

Hasil Penelitian: Menunjukkan bahwa Tekanan, Rasionalisasi, Kompetensi, Arogansi, dan Sifat Machiavellian berpengaruh positif terhadap Fraud Pengelolaan Dana Desa. Sedangkan Kesempatan dan Sifat love of money tidak berpengaruh terhadap Fraud Pengelolaan Dana Desa. Sedangkan Religiusitas terbukti memperlemah pengaruh positif sifat Machiavellian terhadap Fraud Pengelolaan Dana Desa, namun tidak mampu memperlemah pengaruh positif Rasionalisasi dan Sifat love of money terhadap Fraud Pengelolaan Dana Desa.

Keterbatasan Penelitian: (1)Terdapat beberapa item pernyataan kuesioner yang terkadang dapat menyebabkan bias; (2)Menggunakan model teori Fraud Hexagon yang masih tergolong baru, sehingga referensi pembanding masih sangat minim; (3) Terdapat beberapa akses jalan saat pendistribusian kuesioner yang tergolong sedikit berisiko; dan (4) Terdapat pandemik Covid-19 yang menghambat pendistribusian kuesioner.

Keaslian/Novetly Penelitian: Penelitian ini menggunakan pendekatan teori Fraud Hexagon yang masih jarang digunakan. Kemudian untuk penambahan variabel Sifat Machiavellian, dan Sifat love of money belum pernah digunakan untuk meneliti faktor-faktor yang mempengaruhi Fraud Pengelolaan Dana Desa.

\section{(C) 2021 RAB. Published by Universitas Muhammadiyah Yogyakarta} DOI: 10.18196/rabin.v5i1.11688

\section{PENDAHULUAN}

Dana Desa merupakan bagian dari pendanaan yang diterima oleh desa yang berasal dari dana perimbangan keuangan milik pusat ataupun milik daerah yang dialokasikan secara proporsional dan merata untuk desa. Desa merupakan pemerintahan yang langsung berhubungan dengan 
masyarakat serta dijadikan sasaran utama dan terpenting untuk membangun pemerintahan. Undang-undang RI nomor 6 tahun 2014 tentang desa, menyatakan bahwa alokasi dana desa merupakan program pemerintah dalam rangka membangun kesejahteraan masyarakat desa, meningkatkan kualitas pelayanan kepada publik, serta mengembangkan potensi yang ada di desa sehingga desa mampu mandiri dan mempunyai daya saing.

Dengan adanya tujuan-tujuan yang melatarbelakangi dimunculkannya dana desa, pemerintah tidak main-main dalam menganggarkan dananya. Berdasarkan data Kemenkeu, alokasi dana desa dianggarkan terus meningkat dari tahun ke tahun yang awal mulanya pada tahun 2015 saat sedang gencar-gencarnya program tersebut, alokasi dana desa dianggarkan hanya berjumlah 20,7 triliun rupiah, namun pada tahun 2020, alokasi dana desa mencapai 72 triliun dan dialokasikan untuk seluruh desa di Indonesia (www.djpk.kemenkeu.go.id).

Dalam Buku Saku Dana Desa, Menteri Keuangan Republik Indonesia (2017), mengungkapkan hasil evaluasi pelaksanaan dana desa selama 2 tahun yaitu pada periode 2015 dan 2016, bahwa dana desa mampu meningkatkan infrastruktur dan fasilitas yang layak bagi masyarakat desa. Selain itu, dana desa juga dianggap mampu menambah kualitas kehidupan masyarakat desa yang dapat dibuktikan dengan adanya penurunan jumlah rasio ketimpangan di desa dan penurunan jumlah penduduk miskin. Di samping terdapat hasil positif dari adanya program dana desa, ternyata program tersebut juga menyimpan hal yang memprihatinkan pula terkait pengelolaannya, yakni maraknya kasus fraud pada pengelolaan dana desa. Indonesia Corruption Watch (ICW) mencatat bahwa, korupsi dalam pengelolaan dana desa dari tahun ke tahun mengalami peningkatan yang memprihatinkan. Catatan ICW mengenai korupsi pada sektor dana desa selama tahun 2015 sampai dengan tahun 2018 mencapai 264 kasus. ICW mengungkapkan bahwa korupsi dana desa pada tahun 2018 merupakan korupsi yang tertinggi di antara sektor lain dengan mencapai 96 kasus (Jayani, 2019).

Jogja Corruption Watch (JCW) juga mencatat bahwa, tindak pidana korupsi di Provinsi DIY merambah hingga ke desa (Kumparan, 2020). Beberapa di antaranya adalah korupsi dana desa yang dilakukan oleh Kepala Desa Banyurejo, Tempel, Sleman, DIY pada tahun 2015 dan 2016, namun baru terungkap pada pertengahan bulan Juli tahun 2019. Kerugian negara akibat kasus tersebut ditaksir mencapai Rp 633,8 juta. Kemudian ada 2 (dua) aparatur desa yakni Kepala Desa dan Bendahara Desa di Desa Banguncipto, diduga diperkirakan melakukan penyelewengan dana desa sejumlah Rp 1,15 miliar yang berasal dari dana APBDes, dana APBN, dan bantuan dari Pemerintah Kabupaten Kulonprogo DIY selama kurun waktu 2014 hingga 2018. Namun, kasus tersebut juga belum lama terungkap, yaitu pada awal bulan Desember tahun 2019 lalu (www.kumparan.com). Hal tersebut menandakan bahwa tingkat fraud pada pengelolaan dana desa dewasa ini masih sangat besar dan memprihatinkan.

Istilah Fraud atau kecurangan merupakan perilaku seseorang untuk berbuat kesalahan yang disengaja dalam rangka memenuhi tujuan dan manfaat pribadi. Dalam akuntansi, konsep fraud termasuk tindakan yang menyimpang dari prosedur atau standar akuntansi yang sebagaimana harus diterapkan dalam sebuah entitas. Sedangkan apabila yang dimaksud dengan fraud pengelolaan dana desa, berarti tindak kecurangan atau penyimpangan yang terjadi dalam pengelolaan dana desa. Pembahasan mengenai fraud pada umumnya didasarkan pada teori fraud yaitu teori fraud hexagon. Teori fraud hexagon menurut Vousinas (2019), menyebutkan bahwa faktor-faktor yang melatarbelakangi seseorang melakukan fraud terdapat 6 (enam) elemen, yaitu tekanan (pressure), kesempatan (opportunity), rasionalisasi (rationalization), kompetensi (competence), arogansi (arrogance), dan kolusi (collusion). Kemudian terdapat teori atribusi, yang menyebutkan bahwa latar belakang seseorang melakukan sesuatu dapat disebabkan oleh adanya perpaduan antara kekuatan dari dalam (internal) pada diri seseorang dan kekuatan dari luar (eksternal) pada diri seseorang (Ikhsan \& Ishak, 2005).

Faktor pertama yang melatarbelakangi terjadinya fraud yaitu tekanan. Tekanan adalah sebuah desakan untuk berbuat sesuatu yang tidak semestinya atau menyimpang, dikarenakan adanya tekanan baik berasal dalam pribadi individu maupun yang berasal dari luar. Beberapa penelitian empiris yang dilakukan mengenai fraud pada pengelolaan dana desa menggunakan elemen tekanan, menunjukkan bahwa tekanan pekerjaan berpengaruh positif terhadap terjadinya fraud pada 
pengelolaan dana desa (Faradiza, 2018). Penelitian tersebut yakni oleh Said dkk (2018); Pamungkas dan Utomo (2018); Omukaga (2019); Zuberi dan Mzenzi (2019); Apriani (2020). Namun beberapa penelitian tersebut tidak sejalan dengan penelitian oleh Putra dan Rahayu (2019) yang menunjukkan bahwa tekanan pekerjaan tidak mempengaruhi adanya fraud pada pengelolaan dana desa.

Kemudian, elemen fraud hexagon yang kedua adalah kesempatan. Kesempatan merupakan sebuah peluang yang ditemui pegawai untuk melakukan tindak kecurangan ketika melaksanakan pekerjaannya. Menurut penelitian Huefner (2010); Said dkk (2018); Omukaga (2019); Apriani (2020), kesempatan dalam pekerjaan berpengaruh positif terhadap terjadinya fraud. Namun penelitian tersebut tidak sejalan dengan penelitian oleh Putra dan Rahayu (2019), yang menunjukkan bahwa tekanan pekerjaan tidak mempengaruhi terjadinya fraud pada pengelolaan dana desa.

Selanjutnya, faktor rasionalisasi sebagai elemen fraud hexagon yang ketiga merupakan munculnya pikiran untuk membenarkan perilaku atau tindakan yang salah. Penelitian mengenai rasionalisasi sebagai salah satu faktor pemicu terjadinya fraud dilakukan oleh Said dkk (2018); Aini, Prayudi, dan Diatmika (2017); Omukaga (2019); Putra dan Rahayu (2019); Apriani (2020), yang hasilnya menunjukkan bahwa rasionalisasi berpengaruh positif terhadap terjadinya fraud. Namun penelitian tersebut tidak sejalan dengan penelitian oleh Faradiza (2018), yang menunjukkan bahwa rasionalisasi pekerjaan tidak mempengaruhi terjadinya fraud.

Faktor keempat yaitu kompetensi, yang dapat diartikan sebagai kemampuan seseorang untuk dapat menciptakan strategi penyelundupan yang canggih dan dapat mengamankan keadaan dalam rangka memperoleh keuntungan, kemudian mengajak orang lain untuk bekerja sama dalam melakukan aksinya (Marks, 2012). Dalam penelitian oleh Widiyarta, Herawati, dan Atmadja (2017); Aini, dkk (2017); Rahayu, Rahmayati, dan Narulitasari (2018); Omukaga (2019); Apriani (2020), menyatakan bahwa kompetensi berpengaruh positif terhadap korupsi (fraud). Namun berbeda halnya dengan penelitian oleh Wati dan Puspitasari (2017), yang menyatakan bahwa kompetensi (kapabilitas) tidak berpengaruh signifikan terhadap fraud.

Selanjutnya faktor kelima dari elemen fraud hexagon adalah arogansi. Arogansi merupakan perilaku kesombongan dan keegoisan seseorang yang merasa mampu melancarkan aksi kecurangannya, sehingga menimbulkan kepercayaan diri yang tinggi bahwa orang tersebut tidak akan ketahuan dalam melakukan kecurangan dan tidak akan terkena sanksi (Aprilia, 2017). Penelitian Burke (2006), Toscano, Price, dan Scheepers (2018), dan Rahman (2019) menyebutkan hasil bahwa arogansi berpengaruh positif terhadap fraud. Namun berbeda dengan penelitian yang dilakukan oleh Aprilia (2017); Faradiza (2018); dan Agustina, dkk (2019), yang menunjukkan bahwa arogansi tidak berpengaruh terhadap terjadinya fraud.

Kemudian yang terakhir yakni adanya penambahan variabel kolusi pada perkembangan teori fraud hexagon. Menurut Vousinas (2019), kolusi merupakan sebuah persetujuan antara dua orang atau lebih untuk saling melindungi satu sama lain dalam melakukan perbuatan jahatnya dan aksi kecurangannya. Hasil penelitian tentang kolusi oleh Huefner (2010) dan Susandra dan Hartina (2017) menyebutkan bahwa kolusi berpengaruh positif terhadap fraud. Namun penelitian mengenai pengaruh kolusi terhadap terjadinya fraud pada pengelolaan dana desa masih sangat jarang diteliti. Maka dari itu, penelitian ini penting dilakukan untuk menguji kebenaran adanya elemen baru pada teori fraud hexagon yang dikembangkan oleh Vousinas.

Selain menggunakan keenam elemen dari fraud hexagon, dalam penelitian ini juga menambahkan variabel lain seperti machiavellian dan love of money. Machiavellian adalah sebuah desain perilaku sosial yang mengaitkan seseorang untuk menghasut orang lain agar menentang kepentingan umum demi memperoleh keuntungan pribadi (Nikara \& Mimba, 2019). Sedangkan arti dari love of money merupakan perilaku seseorang yang terlalu cinta terhadap uang dan memandang uang sebagai hal yang terpenting dalam hidupnya (Husnurrosyidah, 2019). love of money sudah pernah diteliti oleh Elias dan Farag (2010); Lestari (2018); Kismawadi (2019); Farhan, Helmy, dan Afriyenti (2019); Husnurrosyidah (2019), yang menunjukkan bahwa variabel tersebut berpengaruh terhadap terjadinya fraud. Namun penggunaan variabel love of moneyini masih jarang digunakan dalam penelitian tentang fraud dalam pengelolaan dana desa. Kemudian terkait variabel machiavellian juga sudah pernah diteliti oleh Richmond (2001); Shafer dan Simmons (2008); 
Lestari (2018); dan Nurjanah dan Purnamasari (2020) bahwa machiavellian dapat berpengaruh positif terhadap fraud. Namun, hasil yang berbeda ditunjukkan dalam penelitian Farhan dkk (2019) bahwa machiavellian tidak berpengaruh terhadap fraud. Kemudian penggunaan variabel machiavellian juga masih jarang digunakan dalam penelitian tentang fraud pengelolaan dana desa.

Selain itu, dalam penelitian ini juga menggunakan religiusitas sebagai pemoderasi variabel rasionalisasi, machiavellian, dan sifat love of money. Makna religiusitas sendiri adalah dalamnya ketaatan seseorang dalam menghayati ilmu agama dengan baik dan menerapkannya dalam setiap langkah kehidupannya (Zamzam, Mahdi, \& Ansar, 2017). Secara khusus, religiusitas sebagai variabel pemoderasi rasionalisasi sudah pernah dilakukan oleh Fahjar (2019), yang menunjukkan hasil bahwa religiusitas mampu memperlemah pengaruh positif rasionalisasi terhadap fraud. Namun, hasil yang berbeda ditunjukkan dalam penelitian Putra (2019), yang menyatakan bahwa religiusitas tidak memperlemah pengaruh positif rasionalisasi terhadap fraud.

Kemudian religiusitas sebagai pemoderasi sifat machiavellian terhadap fraud, juga sudah pernah dilakukan oleh Farhan dkk (2019), tetapi hasilnya religiusitas tidak mampu memperlemah pengaruh sifat machiavellian terhadap fraud. Religiusitas sebagai variabel moderasi sifat love of money terhadap fraud pun diteliti oleh Farhan dkk (2019), yang menunjukkan hasil bahwa religiusitas mampu memperlemah pengaruh positif sifat love of money terhadap fraud. Meskipun dalam penelitian sebelumnya ada yang menunjukkan bahwa religiusitas tidak mampu memoderasi beberapa faktor yang mempengaruhi fraud, namun penelitian secara umum menunjukkan hasil yang tidak sejalan akan hal tersebut.

Peran religiusitas secara umum, menurut penelitian yang dilakukan oleh Said dkk (2018) dan Urumsah, Wicaksono, dan Hardinto (2018), menunjukkan hasil bahwa adanya religiusitas dapat meminimalisir terjadinya fraud atau kecurangan. Adanya hasil yang tidak konsisten mengenai penggunaan variabel religiusitas sebagai pemoderasi, maka variabel tersebut masih menarik dan layak untuk diteliti.

Penelitian yang berjudul "Pengaruh Elemen Fraud Hexagon, Machiavellian, dan Love of money terhadap Fraud Pengelolaan Dana Desa dengan Religiusitas sebagai Variabel Pemoderasi" ini merupakan kompilasi dari penelitian Susandra dan Hartina (2017); Rustiarini dkk (2019); Farhan dkk (2019); Apriani (2020). Perbedaan dengan penelitian terdahulu yaitu terletak pada penggunaan sampel, objek penelitian, dan variabel pemoderasi. Penelitian ini diharapkan dapat membuktikan kebenaran elemen kolusi sebagai salah satu faktor terjadinya fraud pada pengelolaan dana desa, mampu memperbaiki ketidak konsistenan pada hasil penelitian terdahulu, serta mampu menambah pengetahuan mengenai pengaruhnya terhadap terjadinya fraud pada pengelolaan dana desa, sehingga seluruh pihak dapat mendeteksi dan melakukan pencegahan fraud pada pengelolaan dana desa menggunakan tinjauan-tinjauan hasil penelitian yang pernah dilakukan sebelumnya.

\section{TINJAUAN LITERATUR DAN PERUMUSAN HIPOTESIS}

\section{Teori Fraud Hexagon}

Teori fraud hexagon merupakan teori yang diperkenalkan oleh Vousinas pada tahun 2019. Model fraud ini merupakan hasil pengembangan dari teori fraud triangle oleh Cressey pada tahun 1953, teori fraud diamond oleh Wolfe dan Hermanson pada tahun 2004, serta model S.C.O.R.E. (Stimulus, Capability, Opportunity, Rationalization, dan Ego) atau biasa dikenal dengan teori fraud pentagon yang dikembangkan oleh Crowe Howarth pada tahun 2011. Teori fraud hexagon menyebutkan bahwa faktor-faktor yang melatarbelakangi seseorang melakukan tindakan fraud terdapat 6 (enam) elemen, yaitu tekanan (pressure), kesempatan (opportunity), rasionalisasi (rationalization), kompetensi (competence), arogansi (arrogance), dan kolusi (collusion).

\section{Teori Atribusi}

Teori atribusi pada awalnya dikembangkan oleh Kelley pada tahun 1967, kemudian diperbaharui lagi oleh Green dan Mitchell pada tahun 1979. Mereka beranggapan bahwa perilaku (gaya) kepemimpinan merupakan akibat dari adanya atribut penyebab. Teori atribusi adalah teori 
yang mendefinisikan pengamatan individu terkait perilaku seseorang didasari oleh faktor internal atau eksternal diri seseorang (Robbins \& Judge, 2009). Teori atribusi menyebutkan bahwa latar belakang seseorang melakukan sesuatu dapat disebabkan oleh adanya perpaduan antara kekuatan dari dalam (internal) pada diri seseorang dan kekuatan dari luar (eksternal) pada diri seseorang (Ikhsan \& Ishak, 2005).

\section{Pengaruh Tekanan terhadap Fraud Pengelolaan Dana Desa}

Tekanan adalah sebuah desakan untuk berbuat sesuatu yang tidak semestinya atau menyimpang, dikarenakan adanya tekanan baik berasal dalam pribadi individu maupun yang berasal dari luar. Menurut Albretch dkk (2012), semakin besar tekanan yang dirasakan oleh seseorang, maka akan semakin besar pula kemungkinan terjadinya fraud. Beberapa penelitian empiris dilakukan oleh Said dkk (2018); Pamungkas dan Utomo (2018); (Faradiza, 2018) Rustiarini dkk (2019); Omukaga (2019); Zuberi dan Mzenzi (2019); Apriani (2020), menunjukkan bahwa tekanan pekerjaan berpengaruh positif terhadap terjadinya fraud pada pengelolaan Dana Desa.

Dalam pengelolaan dana desa, adanya tekanan yang dirasakan oleh aparatur desa membuatnya menjadi terpacu untuk melakukan fraud. Tekanan yang dimaksud dapat berupa kebutuhan keluarga yang mendesak, tekanan target pekerjaan, merasa frustrasi dengan pekerjaan, dan merasa dirinya layak memperoleh imbalan (berasal dari eksternal individu). Adanya dana desa yang digelontorkan sebanyak ratusan juta bahkan hingga mencapai milyaran, menyebabkan tugas dan pekerjaan masing-masing aparatur desa menjadi bertambah, sehingga tekanan pekerjaan mereka pun semakin besar. Hal tersebut juga dapat menjadi penyebab terjadinya fraud pengelolaan dana desa karena dia merasa berhak memiliki kekayaan yang lebih atas penambahan pekerjaannya. Berdasarkan uraian tersebut maka dapat diturunkan hipotesis sebagai berikut:

\section{$\boldsymbol{H}_{i}$ : Tekanan berpengaruh positif terhadap fraud pengelolaan dana desa}

\section{Pengaruh Kesempatan terhadap Fraud Pengelolaan Dana Desa}

Kesempatan merupakan sebuah peluang yang ditemui pegawai untuk melakukan tindak kecurangan ketika melaksanakan pekerjaannya. Semakin besar peluang atau kesempatan dihadapkan kepada seseorang dan didukung oleh pemberian kebebasan yang luas, maka semakin besar pula potensi terjadinya fraud. Maka dari itu, kesempatan merupakan faktor pemicu fraud yang berasal dari luar individu. Penelitian empiris seperti yang dilakukan oleh Huefner (2010); Faradiza (2018), Said dkk (2018); Rustiarini dkk (2019); dan Omukaga (2019); Apriani (2020), menunjukkan bahwa kesempatan dalam pekerjaan berpengaruh positif terhadap terjadinya fraud. Adanya penambahan tugas dan pekerjaan masing-masing aparatur desa dikarenakan adanya alokasi dana desa yang banyak dapat menyebabkan ketidaksiapan antar lini aparatur desa untuk saling mengawasi pekerjaannya. Para aparatur desa merasa mempunyai tanggung jawab penuh terhadap pembagian tugasnya yang tentu saja setiap tugas didasari dengan anggaran dana desa, sehingga ia merasa bahwa itu adalah peluang untuk melakukan fraud dalam pengelolaan dana desa. Selain itu, adanya edukasi yang kurang mengenai penggunaan dana desa, masyarakat awam pun menjadi tidak mengerti akan peranannya untuk ikut serta dalam mengawal pengelolaan dana desa, peluang penyelewengan dana desa semakin besar. Berdasarkan uraian tersebut, maka dapat diturunkan hipotesis sebagai berikut:

\section{$\boldsymbol{H}_{2:}$ Kesempatan berpengaruh positif terhadap fraud pengelolaan dana desa}

\section{Pengaruh Rasionalisasi terhadap Fraud Pengelolaan Dana Desa}

Rasionalisasi merupakan munculnya pikiran dalam diri seseorang untuk membenarkan perilaku atau tindakan yang salah. Penelitian mengenai rasionalisasi sebagai salah satu faktor pemicu terjadinya fraud dilakukan oleh Aini, dkk (2017); Putra dan Rahayu (2019); Apriani (2020), yang hasilnya menunjukkan bahwa rasionalisasi berpengaruh positif terhadap terjadinya fraud. Penelitian 
lain dalam taraf internasional dilakukan oleh Said dkk (2018); Rustiarini dkk (2019); Omukaga (2019), yang menyatakan bahwa Rasionalisasi terbukti menjadi faktor penyebab seseorang melakukan fraud.

Hal itu dapat disebabkan karena adanya pengetahuan yang kurang akan tujuan program alokasi dana desa dapat membuat aparatur desa merasa bahwa tindakannya untuk menggunakan dana desa secara pribadi merupakan hal yang wajar dan lumrah. Kemudian maraknya berita di televisi mengenai kasus korupsi yang dilakukan oleh aparatur negara, namun tidak diimbangi dengan penegakan hukum yang tegas, membuat aparatur desa berpikir bahwa hal tersebut tidak adil untuknya. Pelaku korupsi tersebut sudah mendapatkan banyak uang tetapi tidak ditindak tegas oleh aparat penegak hukum, sehingga ia ingin mengikuti jalan si pelaku korupsi tersebut untuk melakukan korupsi dana desa. Berdasarkan uraian, dapat ditarik hipotesis sebagai berikut:

\section{$\boldsymbol{H}_{3}$ : Rasionalisasi berpengaruh positif terhadap fraud pengelolaan dana desa}

\section{Pengaruh Kompetensi terhadap Fraud Pengelolaan Dana Desa}

Kompetensi dapat diartikan sebagai kemampuan diri seseorang untuk melakukan fraud. Dengan kata lain, kemampuan seseorang untuk dapat menciptakan strategi penyelundupan yang canggih dan dapat mengamankan keadaan dalam rangka memperoleh keuntungan, kemudian mengajak orang lain untuk bekerja sama dalam melakukan aksinya (Marks, 2012). Dalam penelitian oleh Widiyarta dkk (2017); Aini, dkk (2017); Rahayu dkk (2018); Rustiarini dkk (2019); Omukaga (2019); Apriani (2020), menyatakan bahwa kompetensi berpengaruh positif terhadap korupsi (fraud).

Kompetensi apabila terdapat niat jahat dibaliknya, kompetensi justru membuat tingkat fraud yang terjadi semakin besar karena pelaku mampu merekayasa dan memanipulasi pelaporan keuangan dana desa dengan menciptakan pengeluaran-pengeluaran fiktif yang sebenarnya hal tersebut digunakan untuk keperluan pribadinya. Berdasarkan uraian, maka dapat disimpulkan hipotesis sebagai berikut:

\section{$\boldsymbol{H}_{4}$ : Kompetensi berpengaruh positif terhadap fraud pengelolaan dana desa}

\section{Pengaruh Arogansi terhadap Fraud Pengelolaan Dana Desa}

Arogansi merupakan perilaku kesombongan dan keegoisan seseorang yang merasa mampu melancarkan aksi kecurangannya, sehingga menimbulkan kepercayaan diri yang tinggi bahwa orang tersebut tidak akan ketahuan dalam melakukan kecurangan dan tidak akan terkena sanksi (Aprilia, 2017). Penelitian Rahman (2019); Zuberi dan Mzenzi (2019), menyebutkan hasil bahwa arogansi berpengaruh positif terhadap fraud.

Di dalam lingkungan pemerintahan desa, pemimpin tertinggi adalah kepala desa. Kepala desa tentu akan mempercayakan pengelolaan keuangan desa kepada bagian keuangan desa. Bagian keuangan desa ini dapat menjadi angkuh, sombong, dan egois karena merasa menjadi tangan kanan kepala desa dalam mengelola keuangan. Adanya hal tersebut membuat bagian keuangan ini merasa bahwa ia tidak akan ketahuan apabila melakukan kecurangan, karena kepala desa sangat mempercayainya. Sehingga hal tersebut dapat menjadi salah satu faktor yang mempengaruhi terjadinya fraud dalam pengelolaan dana desa. Dari uraian yang telah disebutkan, maka dapat ditarik hipotesis sebagai berikut:

\section{$\boldsymbol{H}_{s:}$ Arogansi berpengaruh positif terhadap fraud pengelolaan dana desa.}

\section{Pengaruh Kolusi terhadap Fraud Pengelolaan Dana Desa}

Kolusi merupakan sebuah persetujuan antara dua orang atau lebih untuk saling melindungi satu sama lain dalam melakukan perbuatan jahatnya dan aksi kecurangannya. Hasil penelitian 
tentang kolusi oleh Susandra dan Hartina (2017) menyebutkan bahwa kolusi berpengaruh positif terhadap fraud. Penelitian lain dengan taraf internasional dilakukan oleh Huefner (2010), yang menyatakan bahwa kolusi merupakan salah satu penyebab seseorang berperilaku curang.

Kolusi merupakan faktor penyebab fraud yang berasal dari dalam diri seseorang, karena kolusi didasari oleh keegoisan. Seseorang dapat memanfaatkan posisi orang lain untuk mengamankan kecurangannya. Seperti halnya antar aparatur desa dapat secara bersama-sama saling berkolusi untuk melakukan kecurangan. Pimpinan desa akan berkolusi dengan bagian pengelolaan dana desa untuk memanipulasi pengeluaran-pengeluaran fiktif dalam pelaporannya. Dengan adanya uraian tersebut, maka dapat diturunkan hipotesis sebagai berikut:

\section{$\boldsymbol{H}_{6:}$ Kolusi berpengaruh positif terhadap fraud pengelolaan dana desa}

\section{Pengaruh Sifat Machiavellian terhadap Fraud Pengelolaan Dana Desa}

Sifat machiavellian ini adalah sifat yang dapat berdampak negatif terhadap sebuah profesi, terutama profesi akuntan, dikarenakan apabila akuntan mempunyai sifat machiavellian ini akan condong mempunyai pikiran manipulatif dalam hidupnya (Fihandoko \& Achsin, 2014). Penelitian empiris mengenai sifat machiavellian dilakukan oleh Lestari (2018) dan Nurjanah dan Purnamasari (2020), yang menunjukkan bahwa machiavellian dapat berpengaruh positif terhadap fraud. Hal tersebut didukung dengan penelitian yang dilakukan oleh Richmond (2001); Shafer dan Simmons (2008), yang menyatakan bahwa machiavellian dapat mempengaruhi tingkat etika seseorang dalam melakukan fraud.

Aparatur desa yang mempunyai sifat machiavellian akan lebih terdorong melakukan fraud dengan memanipulasi laporan-laporan yang ia kerjakan. Selain itu, ia juga dapat mempengaruhi orang lain agar ikut mau menuruti keinginannya dalam mencapai keuntungan pribadi. Sifat Machiavellian mendorong orang untuk selalu melakukan semuanya sesempurna mungkin sehingga dari dalam dirinya tumbuh rasa untuk memanipulasi setiap hal agar semuanya terlihat baik dan sempurna seperti keinginannya. Berdasarkan hal tersebut, maka dapat ditarik hipotesis sebagai berikut:

\section{$\boldsymbol{H}_{7}$ : Sifat Machiavellian berpengaruh positif terhadap fraud pengelolaan dana desa}

\section{Pengaruh Sifat Love of money terhadap Fraud Pengelolaan Dana Desa}

Sifat love of money merupakan perilaku seseorang yang terlalu cinta terhadap uang dan memandang uang sebagai hal yang terpenting dalam hidupnya (Husnurrosyidah, 2019). Sifat love of money sudah pernah diteliti oleh Elias dan Farag (2010); Lestari (2018); Kismawadi (2019); Husnurrosyidah (2019), yang menunjukkan bahwa variabel tersebut berpengaruh terhadap terjadinya fraud. Sifat love of money merupakan sifat yang murni dimiliki oleh pribadi seseorang (dengan kata lain, berasal dari internal seseorang dan bukan dikarenakan faktor eksternal). Dana desa yang dialokasikan ke desa memiliki jumlah yang sangat besar. Apabila satu orang atau lebih aparatur desa mempunyai sifat ini, maka keamanan dana desa dapat terancam. Aparatur desa yang mempunyai sifat love of money akan menganggap semuanya adalah uang, uang, dan uang, serta selalu berpikir untuk bagaimana cara mendapatkan uang yang banyak. Berdasarkan hal yang telah dijelaskan, maka dapat ditarik hipotesis sebagai berikut:

\section{$\boldsymbol{H}_{s}$ : Love of money berpengaruh positif terhadap fraud pengelolaan dana desa}

Pengaruh Religiusitas dalam memoderasi Rasionalisasi terhadap Fraud Pengelolaan Dana Desa

Religiusitas adalah dalamnya ketaatan seseorang dalam menghayati ilmu agama dengan baik dan menerapkannya dalam setiap langkah kehidupannya (Zamzam dkk, 2017). Sedangkan rasionalisasi adalah munculnya pikiran dalam diri seseorang untuk membenarkan perilaku atau 
tindakan yang salah. Religiusitas sebagai variabel pemoderasi rasionalisasi sudah pernah diteliti oleh Fahjar (2019), yang menunjukkan hasil bahwa religiusitas mampu memperlemah pengaruh positif rasionalisasi terhadap fraud. Religiusitas yang tinggi juga terbukti dapat mengurangi kemungkinan seseorang untuk berperilaku buruk (Said dkk, 2018).

Apabila pihak pengelola dana desa mempunyai pemikiran yang rasional mengenai tindakan fraud itu merupakan hal yang dianggap wajar maka hal tersebut dapat menjadi faktor pemicu untuk dirinya melakukan tindakan fraud. Namun apabila seseorang yang mempunyai pemikiran yang rasional dan diimbangi dengan tingkat religiusitas yang tinggi, maka hal tersebut dapat memperlemah atau meminimalisir tingkat terjadinya fraud dalam pengelolaan dana desa. Berdasarkan uraian tersebut, maka dapat dirumuskan hipotesis sebagai berikut:

\section{H.: $_{\text {: }}$ Religiusitas memperlemah pengaruh positif Rasionalisasi terhadap fraud pengelolaan dana desa}

\section{Pengaruh Religiusitas dalam memoderasi Sifat Machiavellian terhadap Fraud Pengelolaan Dana Desa}

Religiusitas adalah dalamnya ketaatan seseorang dalam menghayati ilmu agama dengan baik dan menerapkannya dalam setiap langkah kehidupannya (Zamzam dkk, 2017). Sedangkan sifat machiavellian merupakan karakter personal yang condong untuk memanipulasi agar menghasilkan kesempurnaan. Religiusitas yang tinggi terbukti dapat mengurangi kemungkinan seseorang untuk berperilaku buruk (Said dkk, 2018). Menurut penelitian yang dilakukan oleh Urumsah dkk (2018), juga menunjukkan hasil bahwa adanya religiusitas dapat meminimalisir terjadinya fraud atau kecurangan.

Agama mengajarkan seseorang untuk selalu berbuat baik dan berperilaku etis sesuai dengan etika profesionalnya. Aparatur desa yang mempunyai tingkat religiusitas yang tinggi akan cenderung terhindar dari sifat buruk, salah satunya yaitu terhindar dari sifat machiavellian. Aparatur desa akan bekerja sesuai dengan kewajibannya dengan mengedepankan kejujuran untuk menyajikan laporanlaporan keuangan desa yang wajar dan apa adanya, serta lebih menghargai orang lain. Hal tersebut akan membuat mereka cenderung merasa diawasi oleh Allah SWT dan tingkat religiusitas tersebut akan membuat seseorang berpegang teguh terhadap ajaran agama yang kemudian dapat meminimalisir tindakan fraud dalam pengelolaan dana desa. Berdasarkan uraian, maka dapat dihipotesiskan:

$\boldsymbol{H}_{10}$ : Religiusitas memperlemah pengaruh positif Sifat Machiavellian terhadap fraud pengelolaan dana desa.

\section{Pengaruh Religiusitas dalam memoderasi Sifat Love of money terhadap Fraud Pengelolaan Dana Desa}

Religiusitas adalah dalamnya ketaatan seseorang dalam menghayati ilmu agama dengan baik dan menerapkannya dalam setiap langkah kehidupannya (Zamzam dkk, 2017).. Sedangkan sifat love of money merupakan perilaku seseorang yang terlalu cinta terhadap uang dan memandang uang sebagai hal yang terpenting dalam hidupnya (Husnurrosyidah, 2019). Religiusitas yang tinggi juga terbukti dapat mengurangi kemungkinan seseorang untuk berperilaku buruk (Said dkk, 2018). Kemudian, religiusitas sebagai variabel moderasi sifat love of money terhadap fraud pun diteliti oleh Farhan dkk (2019), yang menunjukkan hasil bahwa religiusitas mampu memperlemah pengaruh positif sifat love of money terhadap fraud.

Adanya sifat love of money dalam diri seseorang tentu saja dapat menjadi penyebab utama terjadinya fraud dalam pengelolaan dana desa. Namun apabila sifat love of money yang dimiliki aparatur desa tersebut masih dibawah batas kewajaran dan diimbangi dengan religiusitas yang tinggi, maka hal tersebut dapat memperlemah pengaruh sifat love of money terhadap terjadinya fraud dalam pengelolaan dana desa karena ajaran agama melarang untuk terlalu mencintai hal-hal yang bersifat duniawi. Berdasarkan uraian tersebut, maka dapat diturunkan hipotesis sebagai berikut: 
$\boldsymbol{H}_{u}$ : Religiusitas memperlemah pengaruh positif Sifat Love of money terhadap fraud pengelolaan dana desa.

\section{METODE PENELITIAN}

\section{Jenis Penelitian}

Penelitian ini merupakan penelitian kuantitatif dengan jenis data yang digunakan adalah data primer. Data dalam penelitian ini diperoleh dari 32 desa yang terdapat di pemerintahan desa Kabupaten Bantul, Kabupaten Gunungkidul, Kabupaten Kulon Progo, dan Kabupaten Sleman yang masing-masing kabupaten dipilih 8 desa dengan jumlah alokasi dana desa tertinggi di DIY.

\section{Populasi}

Populasi dari penelitian ini adalah kantor pemerintahan desa di Provinsi DIY, yang terdiri atas pemerintahan desa Kabupaten Bantul, Kabupaten Gunungkidul, Kabupaten Kulon Progo, dan Kabupaten Sleman. Sampel dalam penelitian ini adalah sebagian perangkat desa di setiap kabupaten yang ada di Provinsi DIY dan dianggap mewakili populasi, yang terdiri dari Kepala Desa, Sekretaris Desa, Kepala Urusan, dan Kepala Seksi.

\section{Teknik Pengambilan Sampel}

Teknik pengambilan sampel yang digunakan dalam penelitian ini adalah teknik Nonprobability Sampling dengan metode Purposive Sampling yaitu teknik pengambilan sampel yang dilakukan dengan cara mengambil sampel dari populasi berdasarkan suatu kriteria tertentu. Kriteria pengambilan sampel dalam penelitian ini adalah aparatur desa yang sudah memiliki pengalaman kerja minimal 2-3 tahun dan mempunyai jabatan tinggi di desa, yaitu Kepala Desa, Sekretaris Desa, Kepala Urusan, dan Kepala Seksi untuk meminimalisir self assessment dalam penilaian kuesioner.

\section{Jenis dan Sumber Data}

Penelitian ini menggunakan teknik pengumpulan data survei penyebaran kuesioner. Teknik survei penyebaran kuesioner adalah metode pengumpulan data secara primer dengan menyediakan butir-butir pertanyaan kepada responden (Hartono, 2016). Kuesioner yang digunakan pada penelitian ini terdiri dari sepuluh bagian di antaranya mengenai tekanan, kesempatan, rasionalisasi, kompetensi, arogansi, kolusi, sifat machiavellian, sifat love of money, fraud pada dana desa, dan religiusitas. Jawaban responden menggunakan skala likert yang berisi lima tingkat jawaban yaitu sangat tidak setuju (STS), tidak setuju (TS), netral (N), setuju (S), dan sangat setuju (SS).

\section{Instrumen Penelitian}

Fraud Pengelolaan Dana Desa

Pengukuran variabel fraud dalam pengelolaan dana desa mengadopsi instrumen Tuanakotta (2007) yang terdiri dari sembilan butir pertanyaan.

Tekanan

Pengukuran variabel tekanan mengadopsi instrumen Albretch dkk (2012) yang terdiri dari tujuh butir pertanyaan.

Kesempatan

Pengukuran variabel kesempatan mengadopsi instrumen Albretch dkk (2012) yang terdiri dari enam butir pertanyaan.

Rasionalisasi

Pengukuran variabel rasionalisasi mengadopsi instrumen Albretch dkk (2012) yang terdiri dari lima butir pertanyaan. 
Kompetensi

Pengukuran variabel kompetensi mengadopsi instrumen Wolfe dan Hermason (2004) yang terdiri dari lima butir pertanyaan.

Arogansi

Pengukuran variabel arogansi mengadopsi instrumen Horwath (2011) yang terdiri dari lima butir pertanyaan.

Kolusi

Pengukuran variabel kolusi mengadopsi instrumen Susandra dan Hartina (2017) yang terdiri dari lima butir pertanyaan.

Sifat Machiavellian

Pengukuran variabel machiavellian mengadopsi instrumen Christien dan Geis (1970) yang terdiri dari lima belas butir pertanyaan.

Sifat Love of Money

Pengukuran variabel love of money mengadopsi instrument Tang (2007) yang terdiri dari delapan butir pertanyaan.

Religiusitas

Pengukuran variabel religiusitas mengadopsi instrument Helmy (2011) yang terdiri dari enam butir pertanyaan.

\section{Teknik Analisis Data}

Hasil kuesioner yang telah disebarkan, kemudian dikumpulkan dan dianalisis menggunakan analisis SEM-PLS (Structural Equation Modeling-Partial Least Square) pada software Smart PLS 3.3.2 versi windows 10. SEM-PLS adalah metode analisis data yang mampu mendeskripsikan konsep model dengan variabel laten (variabel yang tidak bisa diukur secara kongkrit), namun hanya bisa dinilai berdasarkan persepsi atau indikator-indikator tertentu (manifest variables). SEM memberikan kemudahan untuk melakukan analisis jalur (path analytic) dengan variabel laten. PLS merupakan pengujian yang berorientasi pada prediksi dan lebih bersifat non-parametrik (Ghozali \& Latan, 2015).

\section{HASIL DAN PEMBAHASAN}

\section{Gambaran Umum Penelitian}

Penelitian ini dilakukan di kantor pemerintah desa Kabupaten Bantul, Gunungkidul, Kulon Progo, dan Sleman. Adapun desa yang dipilih oleh peneliti merupakan 8 desa dengan penerimaan dana desa tertinggi di setiap kabupaten sehingga menghasilkan 32 desa yang menjadi tempat penelitian. Kuesioner yang disebarkan dalam penelitian ini sebanyak 256 kuesioner kepada aparatur desa yang ada pada setiap kantor desa dengan masing-masing desa mendapatkan 8 kuesioner. Penyebaran dan pengambilan dilakukan mulai tanggal 18 Agustus 2020 hingga tanggal 30 September 2020. 


\section{Uji Statistik Deskriptif}

Tabel 1 Hasil Uji Statistik Deskriptif

\begin{tabular}{lcccccccc}
\hline \multicolumn{1}{c}{ Variabel } & \multirow{2}{*}{ N } & \multicolumn{3}{c}{ Kisaran Aktual } & \multicolumn{3}{c}{ Kisaran Teoretis } & \multicolumn{1}{c}{ Std. } \\
& & Min & Max & Mean & Min & Max & Mean & Deviation \\
\hline Fraud Dana Desa & 203 & 9 & 45 & 26.33 & 9 & 45 & 27 & 12.618 \\
Tekanan & 203 & 7 & 32 & 20.2 & 7 & 35 & 21 & 5.93 \\
Kesempatan & 203 & 6 & 30 & 17.99 & 6 & 30 & 18 & 5.404 \\
Rasionalisasi & 203 & 5 & 25 & 14.6 & 5 & 25 & 15 & 5.93 \\
Kompetensi & 203 & 7 & 22 & 15.18 & 5 & 25 & 15 & 3.379 \\
Arogansi & 203 & 5 & 25 & 14.02 & 5 & 25 & 15 & 5.938 \\
Kolusi & 203 & 5 & 25 & 14.98 & 5 & 25 & 15 & 6.427 \\
Sifat Machiavellian & 203 & 33 & 75 & 51.36 & 15 & 75 & 45 & 9.585 \\
Sifat Love of Money & 203 & 8 & 40 & 24.42 & 8 & 40 & 24 & 6.984 \\
Religiusitas & 203 & 9 & 29 & 22.66 & 6 & 30 & 18 & 4.47 \\
\hline
\end{tabular}

Hasil uji statistik deskriptif pada Tabel 1 memperlihatkan jumlah data yang diolah berjumlah 203 data. Variabel fraud dana desa, tekanan, kesempatan, rasionalisasi, kompetensi, dan kolusi mempunyai mean kisaran aktual < mean kisaran teoretis sehingga rata-rata pengaruh variabelvariabel tersebut di kantor pemerintahan desa di Provinsi Daerah Istimewa Yogyakarta tergolong rendah. Sedangkan variabel kompetensi, sifat Machiavellian, sifat love of money, dan religiusitas mempunyai mean kisaran aktual > mean kisaran teoretis sehingga rata-rata pengaruh variabelvariabel tersebut di kantor pemerintahan desa di Provinsi Daerah Istimewa Yogyakarta tergolong tinggi.

\section{Uji Bias}

Common Method Bias

Bias metode umum digunakan untuk menghindari adanya self assesment bias yang dapat memicu kesalahan dalam pengukuran dengan menggunakan beberapa item pernyataan yang dibalik untuk mengetahui kekonsistenan dalam menjawab setiap item pernyataan.

Non-Response Bias

Tabel 2 Uji Non-Response Bias (Nonparametric Test)

\begin{tabular}{clcl}
\hline \multirow{2}{*}{ No. } & \multicolumn{1}{c}{ Variabel } & \multicolumn{2}{c}{$\begin{array}{c}\text { Independent-Semples } \text { Mann-Whitney } \boldsymbol{U} \text { Test } \\
\text { Sig. }\end{array}$} \\
\hline 1 & Fraud Dana Desa & 0,685 & Retain the null hypothesis \\
2 & Tekanan & 0,073 & Retain the null hypothesis \\
3 & Kesempatan & 0,615 & Retain the null hypothesis \\
4 & Rasionalisasi & 0,998 & Retain the null hypothesis \\
5 & Kompetensi & 0,473 & Retain the null hypothesis \\
6 & Arogansi & 0,473 & Retain the null hypothesis \\
7 & Kolusi & 0,135 & Retain the null hypothesis \\
8 & Sifat Machiavellian & 0,727 & Retain the null hypothesis \\
9 & Sifat Love of Money & 0,812 & Retain the null hypothesis \\
10 & Religiusitas & 0,282 & Retain the null hypothesis \\
\hline
\end{tabular}

Berdasarkan hasil pengujian pada tabel 2 diatas, besaran nilai sig lebih dari 0,05 untuk setiap variabel, maka signifikansinya bernilai sama antara kuesioner yang dikumpulkan pada bulan pertama dan yang dikumpulkan pada bulan kedua, sehingga tidak diperlukan pengujian data secara multi group. 
Uji Common Method Variance

Tabel 3 Uji Common Method Variance (Factor Analyze)

\begin{tabular}{|c|c|c|c|c|c|c|}
\hline \multirow[b]{2}{*}{ Component } & \multicolumn{3}{|c|}{ Initial Eigenvalues } & \multicolumn{3}{|c|}{ Extraction Sums of Squared Loadings } \\
\hline & Total & $\begin{array}{c}\text { 96 of } \\
\text { Variance }\end{array}$ & Cumulative 96 & Total & $\begin{array}{c}96 \text { of } \\
\text { Variance }\end{array}$ & Cumulative 96 \\
\hline 1 & 32.082 & 45.186 & 45.186 & 32.082 & 45.186 & 45.186 \\
\hline
\end{tabular}

Berdasarkan hasil pengujian pada Tabel 3, persentase varian adalah sebesar 45,186\%. Hal tersebut memenuhi kriteria bahwa persentase varian tidak boleh melebihi $50 \%$ yang artinya data tersebut tidak normatif, sehingga data yang digunakan dalam penelitian ini bebas dari bias karena responden menilai kuesioner secara sungguh-sungguh dan apa adanya.

Outer Model

Convergent Validity

Tabel 4 Average Variant Extracted (AVE)

\begin{tabular}{ll}
\hline & AVE \\
\hline Arogansi & 0.824 \\
Fraud Dana Desa & 0.873 \\
Kesempatan & 0.662 \\
Kolusi & 0.935 \\
Kompetensi & 0.979 \\
MO1 & 1.000 \\
MO2 & 1.000 \\
MO3 & 1.000 \\
Rasionalisasi & 0.817 \\
Religiusitas & 0.604 \\
Sifat Love of Money & 0.765 \\
Sifat Machiavellian & 0.602 \\
Tekanan & 0.629 \\
\hline
\end{tabular}

Berdasarkan Tabel 4 seluruh indikator setiap variabel sudah menunjukkan angka lebih dari 0,50 dan sudah memenuhi kriteria syarat pengujian outer loading.

Discriminant Validity

Tabel 5 Fornell Larcker

\begin{tabular}{|c|c|c|c|c|c|c|c|c|c|c|c|c|c|}
\hline & $\mathbf{A}$ & FDD & KS & KL & KP & MO1 & MO2 & MO3 & $\mathbf{R}$ & RLG & LOM & SMC & TK \\
\hline Arogansi & 0.908 & & & & & & & & & & & & \\
\hline FDD & 0.777 & 0.934 & & & & & & & & & & & \\
\hline Kesempatan & 0.711 & 0.765 & 0.814 & & & & & & & & & & \\
\hline Kolusi & 0.582 & 0.603 & 0.624 & 0.967 & & & & & & & & & \\
\hline Kompetensi & 0.747 & 0.858 & 0.754 & 0.598 & 0.989 & & & & & & & & \\
\hline MO1 & 0.522 & 0.230 & 0.277 & 0.274 & 0.220 & 1.000 & & & & & & & \\
\hline $\mathrm{MO} 2$ & 0.557 & 0.222 & 0.280 & 0.270 & 0.202 & 0.863 & 1.000 & & & & & & \\
\hline MO3 & 0.562 & 0.442 & 0.442 & 0.455 & 0.380 & 0.646 & 0.765 & 1.000 & & & & & \\
\hline Rasionalisasi & 0.724 & 0.835 & 0.797 & 0.683 & 0.818 & 0.301 & 0.245 & 0.455 & 0.904 & & & & \\
\hline Religiusitas & 0.111 & -0.257 & -0.258 & -0.196 & -0.230 & 0.325 & 0.378 & 0.005 & -0.240 & 0.777 & & & \\
\hline Sifat LOM & 0.858 & 0.806 & 0.720 & 0.563 & 0.786 & 0.409 & 0.443 & 0.545 & 0.751 & -0.079 & 0.875 & & \\
\hline SMC & 0.755 & 0.861 & 0.788 & 0.652 & 0.843 & 0.273 & 0.309 & 0.549 & 0.828 & -0.281 & 0.869 & 0.776 & \\
\hline Tekanan & 0.840 & 0.728 & 0.730 & 0.553 & 0.644 & 0.521 & 0.549 & 0.507 & 0.683 & 0.138 & 0.781 & 0.708 & 0.793 \\
\hline
\end{tabular}

Berdasarkan Tabel 5, menunjukkan bahwa nilai akar AVE untuk seluruh variabel menunjukkan nilai yang lebih besar dibandingkan dengan nilai hubungannya dengan variabel lain, sehingga dapat disimpulkan bahwa seluruh variabel valid. 
Reliability

Tabel 6 Construct Reliability and Validity

\begin{tabular}{lcc}
\hline & Cronbach's Alpha & Composite Reliability \\
\hline Arogansi & 0.946 & 0.959 \\
Fraud Dana Desa & 0.982 & 0.984 \\
Kesempatan & 0.876 & 0.907 \\
Kolusi & 0.983 & 0.986 \\
Kompetensi & 0.978 & 0.989 \\
MO1 & 1.000 & 1.000 \\
MO2 & 1.000 & 1.000 \\
MO3 & 1.000 & 1.000 \\
Rasionalisasi & 0.944 & 0.957 \\
Religiusitas & 0.882 & 0.899 \\
Sifat Love of Money & 0.948 & 0.958 \\
Sifat Machiavellian & 0.914 & 0.930 \\
Tekanan & 0.874 & 0.907 \\
\hline
\end{tabular}

Berdasarkan Tabel 6 tersebut, menggambarkan bahwa cronbach's alpha dan composite reliability untuk penelitian ini bernilai lebih dari 0,7 . Hal tersebut mengindikasikan bahwa semua konstruk dapat dikatakan reliabel.

\section{Inner Model}

R-Square

Tabel 7 Nilai Adjusted R-Square

\begin{tabular}{lcc}
\hline & R Square & R Square Adjusted \\
\hline Fraud Dana Desa & 0.860 & 0.851 \\
\hline
\end{tabular}

Tabel 7 menunjukkan bahwa variabel Fraud Pengelolaan Dana Desa dipengaruhi sebesar $85,1 \%$ oleh variabel independennya (pengaruh kuat) dan sisanya yaitu sebesar 14,9\% dipengaruhi oleh faktor lain di luar penelitian ini.

Uji Hipotesis dan Pembahasan

Tabel 8 Path Coefficient

\begin{tabular}{lccccc} 
& Symbol & $\begin{array}{c}\text { Original } \\
\text { Sample }\end{array}$ & $\begin{array}{c}\text { T } \\
\text { Statistics }\end{array}$ & $\begin{array}{c}\text { P } \\
\text { Values }\end{array}$ & Simpulan \\
\hline Religiusitas -> Fraud Dana Desa & - & -0.109 & 2.370 & $\mathbf{0 . 0 0 9}$ & - \\
Tekanan -> Fraud Dana Desa & $\mathrm{H}_{1}$ & 0.264 & 3.428 & $\mathbf{0 . 0 0 0}$ & Terdukung \\
Kesempatan -> Fraud Dana Desa & $\mathrm{H}_{2}$ & -0.075 & 1.312 & $\mathbf{0 . 0 9 5}$ & Tidak Terdukung \\
Rasionalisasi -> Fraud Dana Desa & $\mathrm{H}_{3}$ & 0.184 & 2.378 & $\mathbf{0 . 0 0 9}$ & Terdukung \\
Kompetensi -> Fraud Dana Desa & $\mathrm{H}_{4}$ & 0.273 & 4.656 & $\mathbf{0 . 0 0 0}$ & Terdukung \\
Arogansi -> Fraud Dana Desa & $\mathrm{H}_{5}$ & 0.247 & 2.765 & $\mathbf{0 . 0 0 3}$ & Terdukung \\
Kolusi -> Fraud Dana Desa & $\mathrm{H}_{6}$ & -0.055 & 1.023 & $\mathbf{0 . 1 5 3}$ & Tidak Terdukung \\
Sifat Machiavellian -> Fraud Dana Desa & $\mathrm{H}_{7}$ & 0.185 & 2.016 & $\mathbf{0 . 0 2 2}$ & Terdukung \\
Sifat Love of money $>$ Fraud Dana Desa & $\mathrm{H}_{8}$ & -0.013 & 0.179 & $\mathbf{0 . 4 2 9}$ & Tidak Terdukung \\
MO1 -> Fraud Dana Desa & $\mathrm{H}_{9}$ & -0.033 & 0.438 & $\mathbf{0 . 3 3 1}$ & Tidak Terdukung \\
MO2 -> Fraud Dana Desa & $\mathrm{H}_{10}$ & -0.187 & 2.230 & $\mathbf{0 . 0 1 3}$ & Terdukung \\
MO3 -> Fraud Dana Desa & $\mathrm{H}_{\Perp 1}$ & 0.138 & 2.355 & $\mathbf{0 . 0 0 9}$ & Tidak Terdukung \\
\hline
\end{tabular}




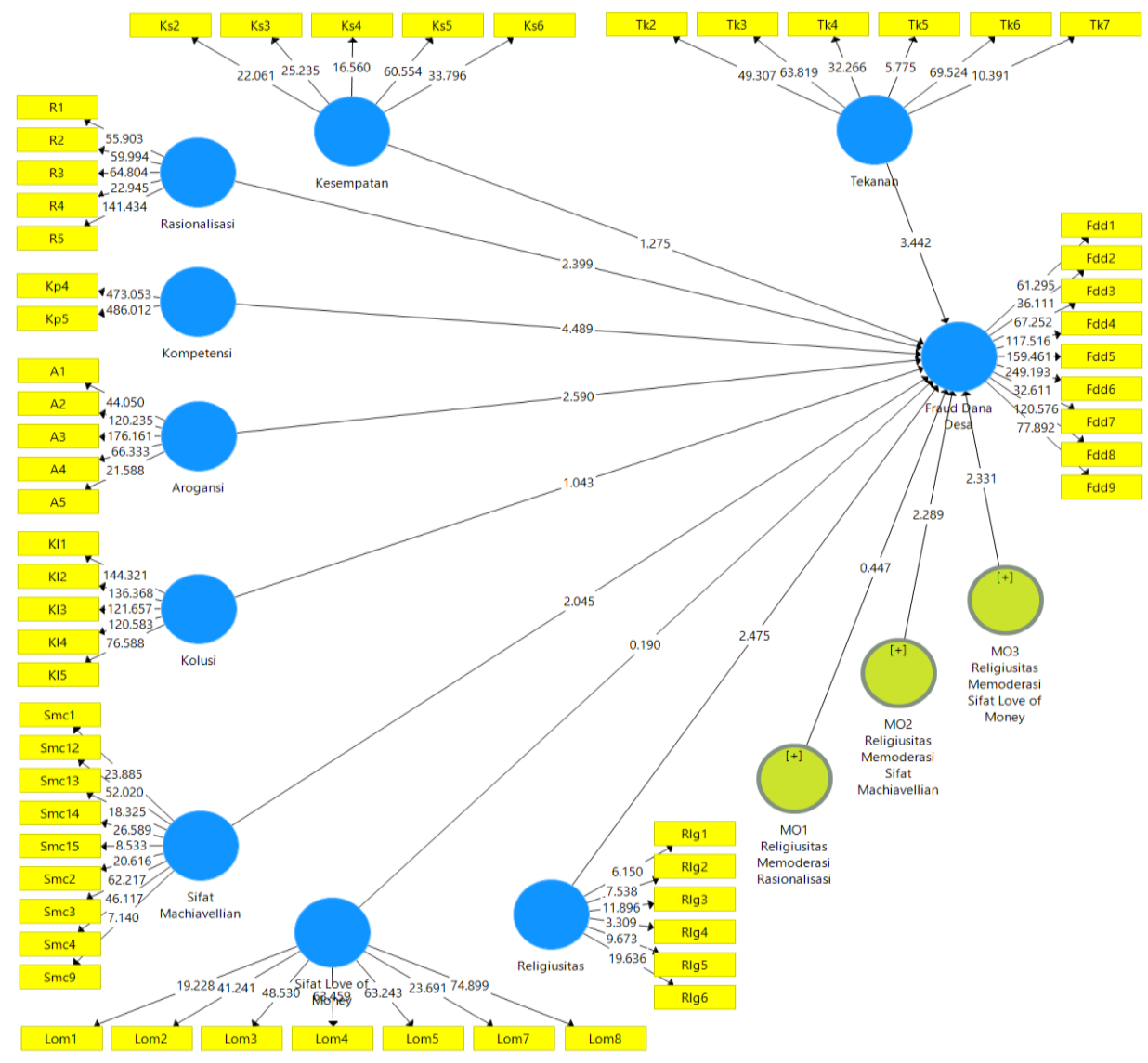

Gambar 1 Calculate Bootstrapping

\section{Pengaruh Tekanan terhadap Fraud Pengelolaan Dana Desa}

Pengujian bootstrapping pada Tabel 8 menunjukkan bahwa original sample bernilai positif sebesar 0,264 sehingga arah pengujian tersebut sesuai dengan arah hipotesis yang dibangun. Sementara itu, nilai t-statistic adalah sebesar 3,428 > 1,66 dan nilai p-values adalah sebesar $0,000<$ 0,05 . Hal tersebut menunjukkan bahwa seluruh kriteria pengujian hipotesis sudah terpenuhi. Dengan demikian dapat ditarik kesimpulan bahwa $\mathrm{H}_{1}$ terdukung. Artinya, tekanan berpengaruh positif signifikan terhadap fraud pengelolaan dana desa.

Tekanan merupakan faktor yang berasal dari dalam maupun luar seseorang. Aparatur desa dalam lingkup kantor pemerintahan desa di provinsi Daerah Istimewa Yogyakarta berperspektif bahwa salah satu penyebab terjadinya fraud dalam pengelolaan dana desa adalah adanya tekanan. Tekanan yang dirasakan oleh aparatur desa membuatnya menjadi terpacu untuk melakukan fraud. Tekanan yang dimaksud dapat berupa kebutuhan keluarga yang mendesak, tekanan target dan beban pekerjaan, merasa frustrasi dengan pekerjaan, serta merasa dirinya layak memperoleh imbalan. Dengan demikian, tekanan merupakan faktor pemicu terjadinya fraud yang berasal dari dalam sekaligus luar individu. Hasil penelitian ini sejalan dengan penelitian yang dilakukan Schuchter \& Levi (2015); Faradiza (2018); Said dkk (2018); Pamungkas dan Utomo (2018); Rustiarini dkk (2019); Putra (2019); Omukaga (2019); Zuberi dan Mzenzi (2019); Apriani (2020).

\section{Pengaruh Kesempatan terhadap Fraud Pengelolaan Dana Desa}

Hasil pengujian hipotesis pada Tabel 8 menunjukkan bahwa original sample bernilai negatif sebesar 0,075 sehingga arah pengujian tersebut tidak sesuai dengan arah hipotesis yang dibangun. Hal tersebut menunjukkan bahwa kriteria pengujian hipotesis tidak terpenuhi. Dengan demikian dapat ditarik kesimpulan bahwa $\mathrm{H}_{2}$ tidak terdukung. Artinya, Kesempatan tidak berpengaruh terhadap fraud pengelolaan dana desa. Penelitian mengenai pengaruh kesempatan terhadap fraud 
juga pernah diteliti oleh Putra (2019), yang mana menghasilkan hasil penelitian yang sejalan dengan penelitian ini.

Kesempatan merupakan faktor yang berasal dari luar seseorang. Beberapa aparatur desa dalam lingkup kantor pemerintahan desa di provinsi Daerah Istimewa Yogyakarta berperspektif bahwa salah satu penyebab terjadinya fraud dalam pengelolaan dana desa adalah adanya kesempatan. Namun kebanyakan tidak setuju akan hal tersebut, kemungkinan di dalam lingkup pemerintahannya sudah menjalankan pekerjaan sebagaimana fungsinya. Kemudian ketika peneliti mendatangi kantor pemerintahan desa yang menjadi objek penelitian, hampir sebagian besar kantor pemerintahan desa sedang melakukan pertemuan/acara Bersama masyarakat. Hal tersebut menguatkan bahwa kesempatan-kesempatan untuk melakukan fraud pun menjadi tidak ada karena intensitas pekerjaan yang begitu membludak. Maka dari itu, hasil penelitian ini menunjukkan bahwa kesempatan bukan salah satu faktor seseorang melakukan fraud.

\section{Pengaruh Rasionalisasi terhadap Fraud Pengelolaan Dana Desa}

Hasil pengujian hipotesis Tabel 8 menunjukkan bahwa original sample bernilai positif sebesar 0,184 sehingga arah pengujian tersebut sesuai dengan arah hipotesis yang dibangun. Sementara itu, nilai t-statistic adalah sebesar 2,378 $>1,66$ dan nilai p-values adalah sebesar 0,009 < 0,05. Hal tersebut menunjukkan bahwa seluruh kriteria pengujian hipotesis sudah terpenuhi. Dengan demikian dapat ditarik kesimpulan bahwa $\mathrm{H}_{3}$ terdukung. Artinya, rasionalisasi berpengaruh positif signifikan terhadap fraud pengelolaan dana desa.

Rasionalisasi merupakan faktor yang berasal dari dalam seseorang. Aparatur desa dalam lingkup pemerintahan desa di provinsi Daerah Istimewa Yogyakarta berperspektif bahwa salah satu penyebab terjadinya fraud dalam pengelolaan dana desa adalah adanya rasionalisasi. Hal itu dapat disebabkan karena adanya pengetahuan yang kurang akan tujuan program alokasi dana desa dapat membuat aparatur desa merasa bahwa tindakannya untuk menggunakan dana desa secara pribadi merupakan hal yang wajar dan lumrah. Kemudian karena marak muncul berita di televisi mengenai kasus korupsi yang dilakukan oleh aparatur negara, namun tidak dïmbangi dengan penegakan hukum yang tegas, membuat aparatur desa berpikir bahwa fraud adalah tindakan yang wajar. Hasil penelitian ini sejalan dengan penelitian yang dilakukan oleh Aini, dkk (2017); Said dkk (2018); Rustiarini dkk (2019); Omukaga (2019); Fahjar (2019); Putra (2019); Apriani (2020).

\section{Pengaruh Kompetensi terhadap Fraud Pengelolaan Dana Desa}

Hasil pengujian hipotesis pada Tabel 8 menunjukkan bahwa original sample bernilai positif sebesar 0,273 sehingga arah pengujian tersebut sesuai dengan arah hipotesis yang dibangun. Sementara itu, nilai t-statistic adalah sebesar 4,656 > 1,66 dan nilai p-values adalah sebesar $0,000<$ 0,05 . Hal tersebut menunjukkan bahwa seluruh kriteria pengujian hipotesis sudah terpenuhi. Dengan demikian dapat ditarik kesimpulan bahwa $\mathrm{H}_{4}$ terdukung. Artinya, kompetensi berpengaruh positif signifikan terhadap fraud pengelolaan dana desa.

Kompetensi merupakan faktor yang berasal dari dalam seseorang. Aparatur desa dalam lingkup pemerintahan desa di provinsi Daerah Istimewa Yogyakarta berperspektif bahwa salah satu penyebab terjadinya fraud dalam pengelolaan dana desa adalah adanya kompetensi. Kompetensi yang dimaksud yakni kemampuan aparatur desa yang tidak digunakan dengan baik, dengan kata lain dimanfaatkan untuk hal-hal yang memicu terjadinya fraud seperti mempengaruhi orang lain atau anggota-anggotanya untuk mengikuti arahannya dalam melakukan fraud tanpa sepengetahuan orang-orang yang memang tidak expert dibidangnya. Dengan demikian, kompetensi merupakan faktor pemicu terjadinya fraud yang berasal dari dalam individu. Hasil penelitian ini sejalan dengan penelitian oleh Wolfe dan Hermason (2004); Ruankew (2016); Zamzam dkk (2017); Widiyarta dkk (2017); Aini, dkk (2017); Rahayu dkk (2018); Faradiza (2018); Omukaga (2019); Putra (2019); Apriani (2020).

\section{Pengaruh Arogansi terhadap Fraud Pengelolaan Dana Desa}

Hasil pengujian hipotesis pada Tabel 8 menunjukkan bahwa original sample bernilai positif sebesar 0,247 sehingga arah pengujian tersebut sesuai dengan arah hipotesis yang dibangun. 
Sementara itu, nilai t-statistic adalah sebesar 2,765 > 1,66 dan nilai p-values adalah sebesar $0,003<$ 0,05 . Hal tersebut menunjukkan bahwa seluruh kriteria pengujian hipotesis sudah terpenuhi. Dengan demikian dapat ditarik kesimpulan bahwa $\mathrm{H}_{s}$ terdukung. Artinya, arogansi berpengaruh positif signifikan terhadap fraud pengelolaan dana desa.

Arogansi merupakan faktor yang berasal dari dalam seseorang. Aparatur desa dalam lingkup pemerintahan desa di provinsi Daerah Istimewa Yogyakarta berperspektif bahwa salah satu penyebab terjadinya fraud dalam pengelolaan dana desa adalah adanya arogansi dimana dalam lingkungan pemerintahan desa, pemimpin tertinggi adalah kepala desa. Kepala desa tentu akan mempercayakan pengelolaan keuangan desa kepada bagian keuangan desa. Bagian keuangan desa ini dapat menjadi angkuh, sombong, dan egois karena merasa menjadi tangan kanan kepala desa dalam mengelola keuangan. Adanya hal tersebut membuat bagian keuangan ini merasa bahwa ia tidak akan ketahuan apabila melakukan kecurangan, karena kepala desa sangat mempercayainya. Sehingga hal tersebut dapat menjadi salah satu faktor yang mempengaruhi terjadinya fraud dalam pengelolaan dana desa yang berasal dari dalam diri individu. Penelitian ini sejalan dengan penelitian Burke (2006); Toscano dkk (2018); Rahman (2019).

\section{Pengaruh Kolusi terhadap Fraud Pengelolaan Dana Desa}

Hasil pengujian hipotesis pada Tabel 8 menunjukkan bahwa original sample bernilai negatif sebesar 0,055 sehingga arah pengujian tersebut tidak sesuai dengan arah hipotesis yang dibangun. Hal tersebut menunjukkan bahwa kriteria pengujian hipotesis tidak terpenuhi. Dengan demikian dapat ditarik kesimpulan bahwa $\mathrm{H}_{6}$ tidak terdukung. Artinya, kolusi tidak berpengaruh terhadap fraud pengelolaan dana desa.

Kolusi merupakan faktor yang berasal dari luar seseorang. Adanya faktor beban kerja yang banyak dengan deadline yang singkat membuat aparatur desa bahkan tidak sempat memikirkan bagaimana cara berkolusi yang aman dan tidak ketahuan. Selain itu, adanya faktor pembagian pekerjaan yang sudah sesuai membuat antar aparatur desa tidak terdapat tumpang tindih pekerjaan yang membuatnya membutuhkan bantuan orang lain, sehingga aparatur desa tidak merasa berhutang budi dan memberi imbalan kepada rekan kerja yang lain. Hal tersebut dapat meminimalisir adanya pengaruh kolusi untuk melakukan sesuatu yang buruk. Hasil penelitian ini sejalan dengan penelitian Putra (2019).

\section{Pengaruh Sifat Machiavellian terhadap Fraud Pengelolaan Dana Desa}

Hasil pengujian hipotesis Tabel 8 menunjukkan bahwa original sample bernilai positif sebesar 0,185 sehingga arah pengujian tersebut sesuai dengan arah hipotesis yang dibangun. Sementara itu, nilai t-statistic adalah sebesar 2,016 > 1,66 dan nilai p-values adalah sebesar 0,022 <0,05. Hal tersebut menunjukkan bahwa seluruh kriteria pengujian hipotesis sudah terpenuhi. Dengan demikian dapat ditarik kesimpulan bahwa $\mathrm{H}_{7}$ terdukung. Artinya, sifat machiavellian berpengaruh positif signifikan terhadap fraud pengelolaan dana desa.

Sifat machiavellian merupakan faktor yang berasal dari dalam seseorang. Aparatur desa dalam lingkup pemerintahan desa di provinsi Daerah Istimewa Yogyakarta berperspektif bahwa salah satu penyebab terjadinya fraud dalam pengelolaan dana desa adalah adanya sifat Machiavellian yang dipunyai oleh individu. Seseorang yang mempunyai sifat tersebut cenderung manipulative dan mudah terdorong untuk melakukan fraud dengan memanipulasi laporan-laporan yang ia kerjakan. Selain itu, ia juga dapat mempengaruhi orang lain agar ikut mau menuruti keinginannya dalam mencapai keuntungan pribadi. Sifat Machiavellian mendorong orang untuk selalu melakukan semuanya sesempurna mungkin sehingga dari dalam dirinya tumbuh rasa untuk memanipulasi setiap hal agar semuanya terlihat baik dan sempurna seperti keinginannya. Dengan demikian, Sifat Machiavellian merupakan faktor pemicu terjadinya fraud yang berasal dari dalam individu. Hasil penelitian ini mendukung penelitian oleh Richmond (2001); Shafer dan Simmons (2008); Lestari (2018); dan Nurjanah dan Purnamasari (2020). 


\section{Pengaruh Sifat Love of money terhadap Fraud Pengelolaan Dana Desa}

Hasil pengujian hipotesis pada Tabel 8 menunjukkan bahwa original sample bernilai negatif sebesar 0,013 sehingga arah pengujian tersebut tidak sesuai dengan arah hipotesis yang dibangun. Hal tersebut menunjukkan bahwa kriteria pengujian hipotesis tidak terpenuhi. Dengan demikian dapat ditarik kesimpulan bahwa $\mathrm{H}_{8}$ tidak terdukung. Artinya, love of money tidak berpengaruh terhadap fraud pengelolaan dana desa.

Love of money merupakan faktor yang berasal dari dalam seseorang. Mayoritas aparatur desa dalam lingkup pemerintahan desa di provinsi Daerah Istimewa Yogyakarta berperspektif bahwa salah satu penyebab terjadinya fraud dalam pengelolaan dana desa bukanlah karena adanya sifat love of money yang dipunyai oleh individu, karena orang-orang di Daerah Istimewa Yogyakarta kebanyakan sangat menjunjung tinggi sifat kehati-hatian dalam menggunakan uang dan cenderung berhemat serta tidak matrealistis, sehingga persepsi kecintaan terhadap uang ialah lebih condong ke arah yang positif yaitu menjaga uang agar tidak terbuang sia-sia dan bukan sebagai salah satu faktor penyebab terjadinya fraud. Aparatur desa akan menerapkan prinsip tersebut ketika ia mengelola dana desa harus berhati-hati dan jangan sampai terbuang sia-sia.

\section{Pengaruh Religiusitas dalam Memoderasi Rasionalisasi terhadap Fraud Pengelolaan Dana Desa}

Hasil pengujian hipotesis pada Tabel 8 menunjukkan bahwa original sample bernilai negatif sebesar 0,033 sehingga arah pengujian tersebut sesuai dengan arah hipotesis yang dibangun. Sementara itu, nilai t-statistic adalah sebesar 0,438 > 1,66 dan nilai p-values adalah sebesar 0,331 > 0,05. Hal tersebut menunjukkan bahwa seluruh kriteria pengujian hipotesis tidak terpenuhi. Dengan demikian dapat ditarik kesimpulan bahwa $\mathrm{H}_{9}$ tidak terdukung. Artinya, religiusitas tidak memperlemah pengaruh positif Rasionalisasi terhadap fraud pengelolaan dana desa.

Religiusitas merupakan faktor yang berasal dari dalam seseorang. Aparatur desa dalam lingkup pemerintahan desa di provinsi Daerah Istimewa Yogyakarta memang berperspektif bahwa adanya fraud yang terjadi dapat disebabkan salah satunya karena faktor rasionalisasi. Hal tersebut dikarenakan intensitas terjadinya fraud dewasa ini sangat besar, sehingga hal tersebut menjadi sesuatu yang dianggap sudah biasa terjadi dan menjadi salah satu faktor yang melatarbelakangi seseorang dapat dengan mudahnya melakukan fraud. Dengan demikian, adanya religiusitas tidak dapat memperlemah pengaruh positif rasionalisasi terhadap fraud. Penelitian ini sejalan dengan penelitian Putra (2019).

\section{Pengaruh Religiusitas dalam Memoderasi Sifat Machiavellian terhadap Fraud Pengelolaan Dana Desa}

Hasil pengujian hipotesis Tabel 8 menunjukkan bahwa original sample bernilai negatif sebesar 0,187 sehingga arah pengujian tersebut sesuai dengan arah hipotesis yang dibangun. Sementara itu, nilai t-statistic adalah sebesar 2,230 > 1,66 dan nilai p-values adalah sebesar 0,013<0,05. Hal tersebut menunjukkan bahwa seluruh kriteria pengujian hipotesis sudah terpenuhi. Dengan demikian dapat ditarik kesimpulan bahwa $\mathrm{H}_{10}$ terdukung. Artinya, religiusitas memperlemah pengaruh positif Sifat Machiavellian terhadap fraud pengelolaan dana desa.

Religiusitas merupakan faktor yang berasal dari dalam seseorang. Aparatur desa dalam lingkup pemerintahan desa di provinsi Daerah Istimewa Yogyakarta akan bekerja sesuai dengan kewajibannya dengan mengedepankan kejujuran untuk menyajikan laporan-laporan keuangan desa yang wajar dan apa adanya, serta lebih menghargai orang lain. Hal tersebut akan membuat mereka cenderung merasa diawasi oleh Allah SWT dan tingkat religiusitas tersebut akan membuat seseorang berpegang teguh terhadap ajaran agama yang kemudian dapat meminimalisir tindakan fraud dalam pengelolaan dana desa. Dengan demikian, adanya religiusitas mampu memperlemah pengaruh positif sifat machiavellian terhadap fraud.

\section{Pengaruh Religiusitas dalam Memoderasi Sifat Love of money terhadap Fraud Pengelolaan Dana Desa}

Hasil pengujian hipotesis Tabel 8 menunjukkan bahwa original sample bernilai positif sebesar 0,138 sehingga arah pengujian tersebut tidak sesuai dengan arah hipotesis yang dibangun. Hal 
tersebut menunjukkan bahwa seluruh kriteria pengujian hipotesis tidak terpenuhi. Dengan demikian dapat ditarik kesimpulan bahwa $\mathrm{H}_{11}$ tidak terdukung. Artinya, religiusitas tidak memperlemah pengaruh positif Sifat love of money terhadap fraud pengelolaan dana desa.

Religiusitas merupakan faktor yang berasal dari dalam seseorang. Aparatur desa dalam lingkup pemerintahan desa di provinsi Daerah Istimewa Yogyakarta memang berperspektif bahwa adanya fraud yang terjadi bukan disebabkan karena faktor sifat love of money. Hal tersebut dikarenakan karena orang-orang di DIY sangat menjunjung tinggi sifat kehati-hatian dalam menggunakan uang dan cenderung berhemat serta tidak matrealistis, sehingga persepsi kecintaan terhadap uang ialah lebih condong kearah yang positif yaitu menjaga uang agar tidak terbuang sia-sia dan bukan sebagai salah satu faktor penyebab terjadinya fraud. Aparatur desa akan menerapkan prinsip tersebut ketika ia mengelola dana desa harus berhati-hati dan jangan sampai terbuang sia-sia. Dengan demikian, adanya religiusitas tidak dapat memperlemah pengaruh positif sifat Love of money terhadap fraud.

\section{KESIMPULAN}

Penelitian ini bertujuan untuk menguji faktor-faktor yang melatarbelakangi seseorang melakukan fraud pada pengelolaan dana desa menggunakan elemen teori fraud hexagon (tekanan, kesempatan, rasionalisasi, kompetensi, arogansi, dan kolusi) yang dihubungkan dengan teori atribusi serta tambahan faktor seperti sifat machiavellian, sifat love of money, serta religiusitas sebagai pemoderasi rasionalisasi, sifat machiavellian, sifat love of money. Penelitian ini dilakukan di kantor pemerintahan desa di provinsi Daerah Istimewa Yogyakarta. Berdasarkan hasil pengujian dan analisis pada penelitian ini, maka dapat ditarik kesimpulan sebagai berikut: Tekanan, Rasionalisasi, Kompetensi, Arogansi, dan Sifat Machiavellian berpengaruh positif signifikan terhadap Fraud Pengelolaan Dana Desa. Sedangkan Kesempatan dan sifat love of money tidak berpengaruh terhadap Fraud Pengelolaan Dana Desa. Sementara itu, Religiusitas mampu memperlemah pengaruh positif Sifat Machiavellian terhadap Fraud Pengelolaan Dana Desa, namun tidak mampu memperlemah pengaruh positif rasionalisasi dan Sifat Love of money terhadap Fraud Pengelolaan Dana Desa

Penelitian ini mempunyai beberapa kelemahan dan keterbatasan, diantaranya: (1)Terdapat beberapa item pernyataan kuesioner yang terkadang dapat menyebabkan bias akibat karena penyusunan kuesioner harus disesuaikan dengan keadaan responden; (2) Penelitian ini menggunakan model teori Fraud Hexagon yang masih tergolong baru, sehingga referensi pembanding masih sangat minim; (3) Terdapat beberapa akses jalan saat pendistribusian kuesioner yang tergolong sedikit berisiko; (4) Terdapat pandemik Covid-19 sebagai salah satu keterbatasan peneliti dalam mendistribusikan kuesioner; dan (5) Peneliti mendistribusikan kuesioner secara langsung tanpa mempertimbangkan kesibukan responden, sehingga dapat mengurangi tingkat objektivitas responden dalam penilaian kuesioner.

Adapun saran dan rekomendasi bagi penelitian selanjutnya sebagai berikut: (1) Metode survei alangkah lebih baik apabila dilengkapi dengan teknik wawancara sehingga hasil penelitian menjadi lebih akurat; (2) Menambah jumlah sampel agar hasil penelitian dapat lebih di menggeneralisasikan populasi; (3) Memperluas objek dan subjek penelitian seperti menambah dari kalangan masyarakat setempat sebagai salah satu pengawas berjalannya program dana desa, agar dapat mengurangi tingkat self assessment oleh aparatur desa; dan (4) Mendesain kuesioner dengan metode pendistribusian online, agar lebih efisiensi waktu dan meminimalisir risiko penyebaran pandemik covid-19 yang dewasa ini masih menjadi kendala bagi seluruh negeri. 


\section{LAMPIRAN}

\section{Fraud Pengelolaan Dana Desa}

\begin{tabular}{|c|c|c|c|c|c|c|}
\hline \multirow{2}{*}{ No } & \multirow{2}{*}{ Item Pertanyaan } & \multicolumn{5}{|c|}{ Jawaban } \\
\hline & & STS & TS & $\mathbf{N}$ & $\mathbf{S}$ & SS \\
\hline 1 & $\begin{array}{l}\text { Suatu indikasi fraud apabila untuk suatu tujuan tertentu, biaya dicatat } \\
\text { lebih besar dari semestinya. }\end{array}$ & & & & & \\
\hline 2 & $\begin{array}{l}\text { Suatu indikasi fraud apabila pencatatan bukti transaksi dilakukan tanpa } \\
\text { otorisasi dari pihak yang berwenang. }\end{array}$ & & & & & \\
\hline 3 & $\begin{array}{l}\text { Suatu indikasi fraud apabila untuk tujuan tertentu harga beli } \\
\text { peralatan/perlengkapan kantor dicatat lebih tinggi. }\end{array}$ & & & & & \\
\hline 4 & $\begin{array}{l}\text { Suatu indikasi fraud apabila pengguna anggaran memasukkan kebutuhan } \\
\text { lain yang tidak sesuai kedalam belanja peralatan gedung kantor. }\end{array}$ & & & & & \\
\hline 5 & $\begin{array}{l}\text { Suatu indikasi fraud para pengguna anggaran menggunakan kuitansi } \\
\text { kosong atas pembelian bahan perlengkapan kantor. }\end{array}$ & & & & & \\
\hline 6 & $\begin{array}{l}\text { Suatu indikasi fraud apabila suatu perlengkapan dan peralatan kantor } \\
\text { yang dibeli tidak sesuai dengan spesisifikasi yang harus dibeli. }\end{array}$ & & & & & \\
\hline 7 & $\begin{array}{l}\text { Bukan suatu indikasi fraud apabila suatu transaksi memiliki bukti } \\
\text { pendukung ganda. }\end{array}$ & & & & & \\
\hline 8 & $\begin{array}{l}\text { Suatu indikasi fraud apabila di instansi saya, apabila ditemukan adanya } \\
\text { pengeluaran tanpa dokumen pendukung. }\end{array}$ & & & & & \\
\hline 9 & $\begin{array}{l}\text { Suatu indikasi fraud apabila sisa anggaran dibagikan kepada pegawai } \\
\text { sebagai bonus. }\end{array}$ & & & & & \\
\hline
\end{tabular}

\section{Tekanan}

\begin{tabular}{|c|c|c|c|c|c|c|}
\hline \multirow{2}{*}{ No } & \multirow{2}{*}{ Pertanyaan } & \multicolumn{5}{|c|}{ Jawaban } \\
\hline & & STS & TS & $\mathbf{N}$ & $\mathbf{S}$ & SS \\
\hline 1 & $\begin{array}{l}\text { Gaji yang dibayarkan/diterima terkadang masih kurang untuk menutupi } \\
\text { kebutuhan }\end{array}$ & & & & & \\
\hline 2 & $\begin{array}{l}\text { Lingkungan pekerjaan mendorong seseorang melakukan hal yang } \\
\text { negative }\end{array}$ & & & & & \\
\hline 3 & Rekan dan atasan mendorong seseorang melakukan hal yang negative & & & & & \\
\hline 4 & $\begin{array}{l}\text { Terkadang atasan tidak menghargai kinerja padahal sudah banyak } \\
\text { berkontribusi melaksanakan pekerjaan untuk instansi }\end{array}$ & & & & & \\
\hline 5 & Merasa posisi/kedudukan teman kerja lebih nyaman & & & & & \\
\hline 6 & $\begin{array}{l}\text { Keluhan dari pihak keluarga karena tidak bisa hidup mewah membuat } \\
\text { pusing }\end{array}$ & & & & & \\
\hline 7 & $\begin{array}{l}\text { Mendapatkan uang yang banyak dapat mengurangi masalah } \\
\text { dalam hal keuangan }\end{array}$ & & & & & \\
\hline
\end{tabular}

\section{Kesempatan}

\begin{tabular}{|c|c|c|c|c|c|c|}
\hline \multirow{2}{*}{ No } & \multirow{2}{*}{ Item Pertanyaan } & \multicolumn{5}{|c|}{ Jawaban } \\
\hline & & STS & TS & $\mathbf{N}$ & $\mathbf{S}$ & SS \\
\hline 1 & $\begin{array}{l}\text { Pengendalian dan pengawasan yang baik membuat pegawai tidak bebas } \\
\text { melakukan apapun }\end{array}$ & & & & & \\
\hline 2 & $\begin{array}{l}\text { Terdapat banyak pegawai yang tidak mempunyai kecakapan dalam } \\
\text { bekerja sesuai dengan kualifikasinya }\end{array}$ & & & & & \\
\hline 3 & $\begin{array}{l}\text { Instansi jarang mengambil tindakan tegas terhadap pegawai yang berbuat } \\
\text { curang kalaupun ada hanya sekedar saja }\end{array}$ & & & & & \\
\hline 4 & $\begin{array}{l}\text { Kurang baiknya komunikasi di instansi membuat informasi tersendat } \\
\text { sehingga terbuka peluang untuk berbuat curang }\end{array}$ & & & & & \\
\hline 5 & $\begin{array}{l}\text { Kecurangan merupakan hal yang biasa terjadi didalam organisasi karena } \\
\text { itu untuk apa dipermasalahkan }\end{array}$ & & & & & \\
\hline 6 & $\begin{array}{l}\text { Meskipun kecurangan itu diyakini ada, namun jarang melakukan audit } \\
\text { mutu internal terhadap pegawai dengan semestinya, sehingga sulit untuk } \\
\text { membuktikannya }\end{array}$ & & & & & \\
\hline
\end{tabular}




\section{Rasionalisasi}

\begin{tabular}{|c|c|c|c|c|c|c|}
\hline \multirow{2}{*}{ No } & \multirow{2}{*}{ Item Pertanyaan } & \multicolumn{5}{|c|}{ Jawaban } \\
\hline & & STS & TS & $\mathbf{N}$ & $\mathbf{S}$ & SS \\
\hline 1 & $\begin{array}{l}\text { Terdapat perbuatan kecurangan yang dilakukan tetapi hanya bersifat } \\
\text { sementara merupakan hal wajar }\end{array}$ & & & & & \\
\hline 2 & Dikarenakan terdesak oleh keadaan maka sah-sah saja berbuat curang & & & & & \\
\hline 3 & Fraud adalah wajar & & & & & \\
\hline 4 & Fraud biasa dilakukan semua orang & & & & & \\
\hline 5 & Fraud merupakan hal besar & & & & & \\
\hline
\end{tabular}

\section{Kompetensi}

\begin{tabular}{|c|c|c|c|c|c|c|}
\hline \multirow{2}{*}{ No } & \multirow{2}{*}{ Item Pertanyaan } & \multicolumn{5}{|c|}{ Jawaban } \\
\hline & & STS & TS & $\mathbf{N}$ & $\mathbf{S}$ & SS \\
\hline 1 & Kedudukan/jabatan tinggi bisa menjadi faktor seseorang melakukan fraud & & & & & \\
\hline 2 & $\begin{array}{l}\text { Orang yang mempunyai kedudukan/jabatan kebanyakan adalah orang yang } \\
\text { tenang menghadapi segala situasi bahkan situasi yang menegangkan sekalipun }\end{array}$ & & & & & \\
\hline 3 & $\begin{array}{l}\text { Dengan kemampuan yang dimiliki, seseorang dapat mempengaruhi rekan } \\
\text { kerjanya untuk mengikuti arahannya }\end{array}$ & & & & & \\
\hline 4 & $\begin{array}{l}\text { Dengan kemampuan yang dimiliki, seseorang dapat menciptakan kebohongan } \\
\text { yang tidak diketahui siapa pun karena mereka tidak mampu melakukannya }\end{array}$ & & & & & \\
\hline 5 & $\begin{array}{l}\text { Dengan kemampuan yang dimiliki, seseorang mampu memanfaatkan situasi } \\
\text { untuk melakukan sesuatu yang tidak benar }\end{array}$ & & & & & \\
\hline
\end{tabular}

\section{Arogansi}

\begin{tabular}{|c|c|c|c|c|c|c|}
\hline \multirow{2}{*}{ No } & \multirow{2}{*}{ Item Pertanyaan } & \multicolumn{5}{|c|}{ Jawaban } \\
\hline & & STS & TS & $\mathbf{N}$ & $S$ & SS \\
\hline 1 & $\begin{array}{l}\text { Sikap sulit menerima orang lain yang tidak sepaham merupakan sifat yang } \\
\text { arogan }\end{array}$ & & & & & \\
\hline 2 & $\begin{array}{l}\text { Sikap menganggap orang yang tidak menyukai diri kita adalah musuh } \\
\text { merupakan sifat yang tidak arogan }\end{array}$ & & & & & \\
\hline 3 & $\begin{array}{l}\text { Sikap seseorang menutupi kelemahan dengan kesombongan yang dimiliki } \\
\text { merupakan sifat yang arogan }\end{array}$ & & & & & \\
\hline 4 & $\begin{array}{l}\text { Sikap merasa lebih baik dari orang lain dengan skill yang dimiliki seseorang } \\
\text { merupakan sifat yang arogan }\end{array}$ & & & & & \\
\hline 5 & $\begin{array}{l}\text { Sikap selalu berkata "ya!" bahkan untuk tugas yang belum tentu bisa } \\
\text { dilakukan oleh seseorang merupakan sifat yang arogan }\end{array}$ & & & & & \\
\hline
\end{tabular}

\section{Kolusi}

No

Ketika melakukan perbuatan kecurangan atau berupaya menutupinya,

1 seseorang yang termotivasi atas perbuatan tersebut dapat juga berkolusi dengan berbagai pihak seperti:

a. Teman

b. Teman Kerja Sekantor

c. Atasan

d. Inspektorat Jendral

e. Pegawai pemerintah yang korup 


\section{Sifat Machiavelian}

\begin{tabular}{|c|c|c|c|c|c|c|}
\hline \multirow{2}{*}{ No } & \multirow{2}{*}{ Item Pertanyaan } & \multicolumn{5}{|c|}{ Jawaban } \\
\hline & & STS & TS & $\mathbf{N}$ & $\mathbf{S}$ & SS \\
\hline 1 & $\begin{array}{l}\text { Cara terbaik untuk mengendalikan orang lain adalah dengan mengatakan } \\
\text { sesuatu yang ia kehendaki, sehingga mereka cenderung mempercayai kita }\end{array}$ & & & & & \\
\hline 2 & $\begin{array}{l}\text { Seseorang yang sepenuhnya percaya pada orang lain akan mendapat } \\
\text { kesulitan }\end{array}$ & & & & & \\
\hline 3 & Sulit untuk maju dan berkembang tanpa melakukan jalan pintas & & & & & \\
\hline 4 & Kejujuran adalah hal terbaik dalam kondisi apapun. & & & & & \\
\hline 5 & $\begin{array}{l}\text { Lebih aman bila kita mengasumsikan bahwa semua orang termasuk saya } \\
\text { memiliki sisi jahat (buruk) yang akan dapat muncul jika diberi } \\
\text { kesempatan. }\end{array}$ & & & & & \\
\hline 6 & $\begin{array}{l}\text { Seseorang hanya melakukan suatu tindakan yang ia yakini bahwa } \\
\text { tindakan itu merupakan tindakan yang benar }\end{array}$ & & & & & \\
\hline 7 & Memuji orang yang penting dalam karir kita adalah perbuatan bijaksana. & & & & & \\
\hline 8 & $\begin{array}{l}\text { Dalam segala hal rendah hati dan jujur lebih baik daripada terpandang } \\
\text { (berkuasa) dan tidak jujur. }\end{array}$ & & & & & \\
\hline 9 & $\begin{array}{l}\text { Ketika ada seseorang mengatakan bahwa setiap menit lahir seorang yang } \\
\text { mudah kena tipu, merupakan perkataan yang benar }\end{array}$ & & & & & \\
\hline 10 & Kebaikan harus untuk dilakukan dalam segala hal. & & & & & \\
\hline 11 & Sebagian besar orang pada dasarnya adalah baik dan menyenangkan. & & & & & \\
\hline 12 & Tidak ada alasan apapun untuk berbohong pada orang lain. & & & & & \\
\hline 13 & $\begin{array}{l}\text { Secara umum dapat dikatakan bahwa orang tidak mau bekerja keras } \\
\text { kecuali jika dipaksa untuk melakukannya. }\end{array}$ & & & & & \\
\hline 14 & $\begin{array}{l}\text { Perbedaan terbesar antar narapidana dengan orang lain adalah bahwa } \\
\text { narapidana tidak sepandai orang lain sehingga dapat tertangkap. }\end{array}$ & & & & & \\
\hline 15 & Kebanyakan orang adalah pemberani. & & & & & \\
\hline
\end{tabular}

\section{Sifat Love of money}

\begin{tabular}{|c|c|c|c|c|c|c|}
\hline \multirow{2}{*}{ No } & \multirow{2}{*}{ Item Pertanyaan } & \multicolumn{5}{|c|}{ Jawaban } \\
\hline & & STS & TS & $\mathbf{N}$ & $\mathbf{S}$ & SS \\
\hline 1 & Uang merupakan faktor yang sangat penting bagi kehidupan kita semua. & & & & & \\
\hline 2 & Uang adalah akar dari segala kejahatan. & & & & & \\
\hline 3 & Uang melambangkan prestasi seseorang. & & & & & \\
\hline 4 & Uang membuat seseorang dihormati dalam sebuah komunitas. & & & & & \\
\hline 5 & Uang dapat membuat seseorang memiliki banyak teman. & & & & & \\
\hline 6 & Menggunakan uang dengan sangat berhati-hati adalah suatu hal yang tidak perlu & & & & & \\
\hline 7 & $\begin{array}{l}\text { Membayar semua tagihan dengan segera agar tidak terkena denda dan bunga } \\
\text { adalah suatu hal yang sangat penting }\end{array}$ & & & & & \\
\hline 8 & $\begin{array}{l}\text { Uang memberikan kesempatan bagi seseorang untuk menjadi apa yang } \\
\text { diinginkan. }\end{array}$ & & & & & \\
\hline
\end{tabular}

\section{Religiusitas}

\begin{tabular}{|c|c|c|c|c|c|}
\hline \multirow{2}{*}{ No } & \multirow{2}{*}{ Item Pertanyaan } & \multicolumn{4}{|c|}{ Jawaban } \\
\hline & & STS & $\mathrm{TS}$ & $\mathbf{N} S$ & SS \\
\hline 1 & $\begin{array}{l}\text { Minimal satu kali setiap minggu datang ke tempat ibadah adalah suatu hal } \\
\text { yang sangat penting }\end{array}$ & & & & \\
\hline 2 & Setiap tindakan harus semata-mata dilakukan karena ajaran agama & & & & \\
\hline 3 & $\begin{array}{l}\text { Seseorang lebih mengutamakan membayar sumbangan keagamaan } \\
\text { meskipun bukan menggunakan uang pribadinya (melainkan dengan } \\
\text { menggunakan uang kas desa) }\end{array}$ & & & & \\
\hline 4 & $\begin{array}{l}\text { Rutin memberikan sumbangan Keagamaan adalah suatu hal yang sangat } \\
\text { penting }\end{array}$ & & & & \\
\hline 5 & $\begin{array}{l}\text { Seorang tidak menggunakan uang kas desa untuk kepentingannya sendiri } \\
\text { karena ada dorongan keyakinan agama yang dianut. }\end{array}$ & & & & \\
\hline 6 & $\begin{array}{l}\text { Seseorang boleh mengambil sedikit uang kas desa karena ia merasa rutin } \\
\text { dalam memberikan sumbangan keagamaan }\end{array}$ & & & & \\
\hline
\end{tabular}




\section{DAFTAR PUSTAKA}

Aini, N., Prayudi, M. A., \& Diatmika, P. G. (2017). Pengaruh perspektif fraud diamond terhadap kecenderungan terjadinya kecurangan (fraud) dalam pengelolaan keuangan desa. e-Journal S1 Ak Universitas Pendidikan Ganesha, 8(2), 1-13. Diakses dari https://ejournal.undiksha.ac.id/index.php/S1ak/article/view/14583/8903

Albretch, W. S., Albretch, C. O., Albretch, C.C., \& Zimbelman, M.F. (2012). Fraud examination (Edisi ke-4). Boston: Cengage Learning.

Apriani, U. (2020). Pengaruh komponen-komponen fraud star terhadap korupsi dengan Sistem Pengendalian Intern Pemerintah (SPIP) sebagai variabel moderasi (Studi kasus pada Mahkamah Agung RI). Jurnal Magister Akuntansi Trisakti, 7(1), 1-24. http://dx.doi.org/10.25105/jmat.v7i1.6311

Aprilia, A. (2017). Analisis pengaruh fraud pentagon terhadap kecurangan laporan keuangan menggunakan beneish model pada perusahaan yang menerapkan Asean corporate governance scorecard. Jurnal ASET (Akuntansi Riset), $9(1), \quad$ 101-132. https://doi.org/10.17509/jaset.v9i1.5259

Burke, R. J. (2006). Why leaders fail: exploring the darkside. International Journal of Manpower, 27(1), 91-100. https://doi.org/10.1108/01437720610652862

Elias, R., \& Farag, M. (2010). The relationship between accounting students' love of money and their of money and their ethical perception. Managerial Auditing Journal, 25(3), 269-281. https://doi.org/10.1108/02686901011026369

Fahjar, F. (2019). Determinan fraud dana desa: Analisis fraud pentagon (Studi empiris pada aparatur pemerintah desa di lingkup pemerintahan desa provinsi Daerah Istimewa Yogyakarta). Skripsi. Universitas Muhammadiyah Yogyakarta.

Faradiza, S. A. (2019). Fraud pentagon dan kecurangan laporan keuangan. EkBis:Jurnal Ekonomi dan Bisnis, 2(1), 1-22. https://doi.org/10.14421/ekbis.2018.2.1.1060

Farhan, M., Helmy, H., \& Afriyenti, M. (2019). Pengaruh machiavellian dan love of money terhadap persepsi etika penggelapan pajak dengan religiusitas sebagai variabel moderasi (Studi empiris pada wajib pajak di Kota Padang).Jurnal Eksplorasi Akuntansi, 1(1), 470-486. Diakses dari http://jea.ppj.unp.ac.id/index.php/jea/article/view/88

Fihandoko, S., \& Achsin, M. (2014). Pengaruh sifat sinisme, lingkungan, dan sifat machiavellian terhadap tindakan kecurangan akademik. Jurnal Ilmiah Mahasiswa FEB Universitas Brawijaya, 3(1). Diakses dari https://jimfeb.ub.ac.id/index.php/jimfeb/article/view/1423

Ghozali, I., \& Latan, H. (2015). Partial least squares: Konsep, teknik, dan aplikasi menggunakan program SmartPLS 3.0 (Untuk Penelitian Empiris) (Edisi ke-2). Semarang: Universitas Diponegoro.

Hartono, J. (2016). Metodologi penelitian bisnis salah kaprah dan pengalaman-pengalaman (Edisi ke-6). Yogyakarta: BPFE.

Helmy, H. (2011). The effect of economic and non economic motives on tax compliance. Proceeding of International Conference Political Economy of Trade Liberalization in Developing East Asia: Sustainability, Governance and The Role of Small Business.

Huefner, R. J. (2010). Local government fraud: The Roslyn School District case. Management Research Review, 33(3), 198-209. https://doi.org/10.1108/01409171011030363

Husnurrosyidah, H. (2019). Pengendalian internal, love of money terhadap kecenderungan kecurangan akuntansi di BMT Kabupaten Kudus. EkoNiKa: Jurnal Ekonomi Universitas Kadiri, 4(2), 140-156. https://doi.org/10.30737/ekonika.v4i2.434

Ikhsan, A., \& Ishak, M. (2005). Akuntansi keperilakuan. Jakarta: Salemba Empat.

Jayani, D.H. (2019). Korupsi anggaran desa tertinggi di antara sektor lain. Diakses dari Kata data https://databoks.katadata.co.id/datapublish/2019/11/13/korupsi-anggaran-desa-tertinggidiantara-sektor-lain

Kismawadi, E. R. (2019). Determinan fraud pada penggunaan dana desa studi kasus gampong/desa di kota Langsa. Ihtiyath: Jurnal Manajemen Keuangan Syariah, 3(1). https://doi.org/10.32505/ihtivath.v3i1.1298 
Kumparan. (2020). JCW: Perilaku korupsi di Yogyakarta merambah ke tingkat desa. Diakses dari https://kumparan.com/tugujogja/jcw-perilaku-korupsi-di-yogyakarta-merambah-ke-tingkatdesa-1sZ1486ZAbs

Lestari, N. (2018). Pengaruh love of money dan machiavellian terhadap kecenderungan fraud accounting dalan penggunaan dana desa dengan moralitas individu sebagai variabel moderating (Studi pada desa se kecamatan Mangkutana Kabupaten Luwu Timur). Skripsi. UIN Alauddin Makassar. Diakses dari http://repositori.uin-alauddin.ac.id/id/eprint/12794

Marks, J. (2012). The mind behind the fraudsters crime: Key behavioral and environmental. Crowe Horwath LPP.

Nikara, I., \& Mimba, N. (2019). Pengaruh love of money, machiavellian, idealisme dan religiusitas pada persepsi etis mahasiswa akuntansi. E-Jurnal Akuntansi Universitas Udayana, 26(1), 536562. https://doi.org/10.24843/eja.2019.v26.i01.p20

Nurjanah, N., \& Purnamasari, P. (2020). Pengaruh sifat machiavellian terhadap kecenderungan fraud accounting dengan moralitas individu sebagai variabel moderasi. Prosiding Akuntansi Universitas Islam Bandung.

Omukaga, K. O. (2019). Is the fraud diamond perspective valid in Kenya? Journal of Financial Crime, 1359-0790. https://doi.org/10.1108/ffc-11-2019-0141

Pamungkas, I., \& Utomo, S. (2018). Fraudulent financial reporting: An application of fraud pentagon theory to association of Southeast Asian nations corporate governance scorecard. Journal of Advanced Research in Law and Economics, 9(5), 1729-1737. Diakses dari https://doi.org/10.14505//jarle.v9.5(35).26

Putra, M. A., \& Rahayu, N. T. (2019). Analisis fraud diamond theory dalam pengelolaan dana desa di kecamatan Guntur kabupaten Demak. Prosiding Seminar Nasional Unimus.

Putra, M.I.Y. (2019). Pengaruh fraud hexagon terhadap fraud asset missappropriation yang dimoderasi oleh religiusitas pada Bank Syariah di Jakarta. Skripsi. Universitas Trisakti. Diakses dari

http://repository.trisakti.ac.id/usaktiana/index.php/home/detail/detail_koleksi/2/SKR/2018/0 $0000000000000098244 / 0$

Rahayu, D., Rahmayati, A., \& Narulitasari, D. (2018). Determinan pencegahan fraud pengelolaan keuangan desa. Among Makarti, 11(22). http://dx.doi.org/10.52353/ama.v11i2.170

Rahman, A. (2019). Analisis faktor-faktor yang mempengaruhi kecurangan laporan keuangan dalam perspektif fraud pentagon. JAF-Journal Of Accounting And Finance, 3(2), 34-44. https://doi.org/10.25124/jaf.v3i2.2229

Richmond, K. (2001). Ethical reasoning, machiavellian behavior, and gender: the impact on accounting student's ethical decision making. Disertasi, Blacksburg, Virginia. Diakses dari https://vtechworks.lib.vt.edu/handle/10919/27235

Robbins, S., \& Judge. (2009). Perilaku Organisasi. Jakarta: Salemba Empat.

Rustiarini, N., Sutrisno, T., Nurkholis, \& Andayani, W. (2019). Why people commit public procurement fraud? the fraud diamond view. Journal of Public Procurement, 19(4), 345-362. https://doi.org/10.1108/jopp-02-2019-0012

Said, J., Alam, M., Karim, Z., \& Johari, R. (2018). Integrating religiosity into fraud triangle theory: Findings on Malaysian police officers. Journal of Criminological Research, Policy and Practice, 4(2), 111-123. https://doi.org/10.1108/jcrpp-09-2017-0027

Schuchter, A., \& Levi, M. (2013). The fraud triangle revisited. Security Journal, 29(2), 107-121. https://doi.org/10.1057/sj.2013.1

Shafer, W. E., \& Simmons, R. S. (2008). Social responsibility, Machiavellianism and tax avoidance. Accounting, Auditing \& Accountability Journal, 21(5), 695-720. https://doi.org/10.1108/09513570810872978

Susandra, F., \& Hartina, S. (2017). Analisis faktor-faktor yang mempengaruhi kecenderungan fraud pada satuan kerja perangkat daerah (SKPD) di kota Bogor. Jurnal Akunida, 3(2), 35. https://doi.org/10.30997/jakd.v3i2.987 
Tang, T. L.-P., \& Chen, Y.-J. (2007). Intelligence vs. wisdom: The love of money, machiavellianism, and unethical behavior across college major and gender. Journal of Business Ethics, 82(1), 126. https://doi.org/10.1007/s10551-007-9559-1

Toscano, R., Price, G., \& Scheepers, C. (2018). The impact of CEO arrogance on top management team attitudes. European Business Review, 30(6), 630-644. https://doi.org/10.1108/ebr-12$\underline{2016-0156}$

Tuanakotta, T. (2010). Akuntansi Forensik \& Audit Investigatif. Jakarta: Salemba Empat.

Urumsah, D., Wicaksono, A. P., \& Hardinto, W. (2018). Pentingkah nilai religiusitas dan budaya organisasi untuk mengurangi kecurangan? Jurnal Akuntansi Multiparadigma, 9(1), 156-172. https://doi.org/10.18202/jamal.2018.04.9010

Vousinas, G. L. (2019). Advancing theory of fraud: The S.C.O.R.E. model. Journal of Financial Crime, 26(1), 372-381. https://doi.org/10.1108/jfc-12-2017-0128

Wati, C., \& Puspitasari, W. (2017). Pengaruh fraud diamond, corporate governance, dan kompleksitas bank terhadap financial statement fraud pada perusahaan perbankan. Jurnal Akuntansi Trisakti, 4(2), 157-168. http://dx.doi.org/10.25105/jat.v4i2.4856

Widiyarta, K., Herawati, N. T., \& Atmadja, A. T. (2017). Pengaruh kompetensi aparatur, budaya organisasi, whistleblowing, dan sistem pengendalian internal terhadap pencegahan fraud dalam pengelolaan dana desa (Studi empiris pada pemerintah desa di Kabupaten Buleleng). e-Journal S1 Ak Universitas Pendidikan Ganesha, 8(2). Diakses dari https://ejournal.undiksha.ac.id/index.php/S1ak/article/view/13930

Zamzam, I., Mahdi, S. A., \& Ansar, R. (2017). Pengaruh diamond fraud dan tingkat religiusitas terhadap kecurangan akademik (Studi pada mahasiswa S-1 di lingkungan perguruan tinggi sekota Ternate. Jurnal Ilmiah Akuntansi Peradaban, 3(2). Diakses dari http://journal.uinalauddin.ac.id/index.php/jiap/article/view/4546

Zuberi, O., \& Mzenzi, S. I. (2019). Analysis of employee and management fraud in Tanzania. Journal of Financial Crime, 26(2), 412-431. https://doi.org/10.1108/jfc-01-2018-0012 